\title{
Altering the Stereoselectivity of Whole-Cell Biotransformations via the Physicochemical Parameters Impacting the Processes
}

\author{
Agnieszka Raczyńska, Joanna Jadczyk and Małgorzata Brzezińska-Rodak * \\ Department of Biochemistry, Molecular Biology and Biotechnology, Faculty of Chemistry, \\ Wrocław University of Science and Technology, Wybrzeże Stanisława Wyspiańskiego 27, \\ 50-370 Wrocław, Poland; 233806@student.pwr.edu.pl (A.R.); 246330@student.pwr.edu.pl (J.J.) \\ * Correspondence: malgorzata.brzezinska-rodak@pwr.edu.pl
}

check for updates

Citation: Raczyńska, A.; Jadczyk, J.; Brzezińska-Rodak, M. Altering the Stereoselectivity of Whole-Cell Biotransformations via the Physicochemical Parameters Impacting the Processes. Catalysts 2021, 11, 781. https://doi.org/ $10.3390 /$ catal11070781

Academic Editor: Agatha Bastida Codina

Received: 11 May 2021

Accepted: 24 June 2021

Published: 27 June 2021

Publisher's Note: MDPI stays neutral with regard to jurisdictional claims in published maps and institutional affiliations.

Copyright: (c) 2021 by the authors. Licensee MDPI, Basel, Switzerland. This article is an open access article distributed under the terms and conditions of the Creative Commons Attribution (CC BY) license (https:/ / creativecommons.org/licenses/by/ $4.0 /)$.

\begin{abstract}
The enantioselective synthesis of organic compounds is one of the great challenges in organic synthetic chemistry due to its importance for the acquisition of biologically active derivatives, e.g., pharmaceuticals, agrochemicals, and others. This is why biological systems are increasingly applied as tools for chiral compounds synthesis or modification. The use of whole cells of "wildtype" microorganisms is one possible approach, especially as some methods allow improving the conversion degrees and controlling the stereoselectivity of the reaction without the need to introduce changes at the genetic level. Simple manipulation of the culture conditions, the form of a biocatalyst, or the appropriate composition of the biotransformation medium makes it possible to obtain optically pure products in a cheap, safe, and environmentally friendly manner. This review contains selected examples of the influence of physicochemical factors on the stereochemistry of the biocatalytic preparation of enantiomerically pure compounds, which is undertaken through kinetically controlled separation of their racemic mixtures or reduction of prochiral ketones and has an effect on the final enantiomeric purity and enantioselectivity of the reaction.
\end{abstract}

Keywords: whole-cell; biocatalyst; enantiomerically pure products; influence of external factors

\section{Introduction}

Biocatalysis can be defined as the use of enzymes of different origins to conduct chemical reactions to obtain desired derivatives. These can be catalyzed by whole-cell [1] enzymatic systems or by isolated enzymes [2]. Due to ecological and environmental reasons, biocatalysis has been introduced into industrial applications [3]. The main advantage of this solution is the possibility of obtaining compounds that cannot be synthesized by traditional chemical catalysis but only by using biocatalysts operating with high enantio-, regio-, and chemoselectivity. Biocatalytic reactions are often simpler than traditional processes and of relatively lower cost and they are accompanied by the production of small amounts of waste and byproducts. Additionally, as they do not involve applying harmful heavy metals and strong acids, such as sulfuric (VI) acid or hydrochloric acid, as catalysts, they are safer for the environment [2-4].

Like any other chemical procedure, biocatalysis has some disadvantages, and therefore there is still a need to improve this approach. Limitations can be caused by problems with the stability and activity of the biocatalyst and/or difficulty in culturing of microorganisms and the repeatability of the results. Biocatalysis based on the use of isolated enzymes can generate problems related to the isolation and purification of enzymes. Sometimes parameters such as temperature, $\mathrm{pH}$, or stirring can affect the enzymatic activity (too high or too low may lead to biocatalyst deactivation). Moreover, poor solubility or stability of the substrates in the reaction medium and problems with increasing the scale of the biotransformation process can be considered as difficulties [2-4].

However, biocatalysis is considered a process compatible with the main assumptions of green chemistry and its selectivity and lack of byproducts make it an attractive alternative 
for industry, especially in the case of the synthesis of pharmaceuticals where optical purity is an important aspect [3]. Therefore, a crucial feature of biocatalysis is enantioselectivity, i.e., the ability to produce optical isomers of high enantiomeric excess [4]. The optical purity of the molecule is a key factor for the manifestation of the biological properties of particular isomers. One may be a cure, while the other may be extremely dangerous to health or even lethal [5].

Application of the whole-cell enzymatic system, due to the presence of varied enzymes of opposite stereoselectivities, may result in products of unsatisfactory enantiomeric excess (e.e.). This can be solved by engineering of the reaction parameters, the structure of the substrates, and the mode of the biocatalysis (Scheme 1). These methods involve optimization of both the biocatalyst preparation method (e.g., immobilization, cultivation parameters, introduction of the additional preincubation period) and the conditions of the biotransformation itself (e.g., media engineering; using chemical additives influencing biocatalyst activity; selection of physicochemical parameters: temperature, $\mathrm{pH}$, duration, etc.).

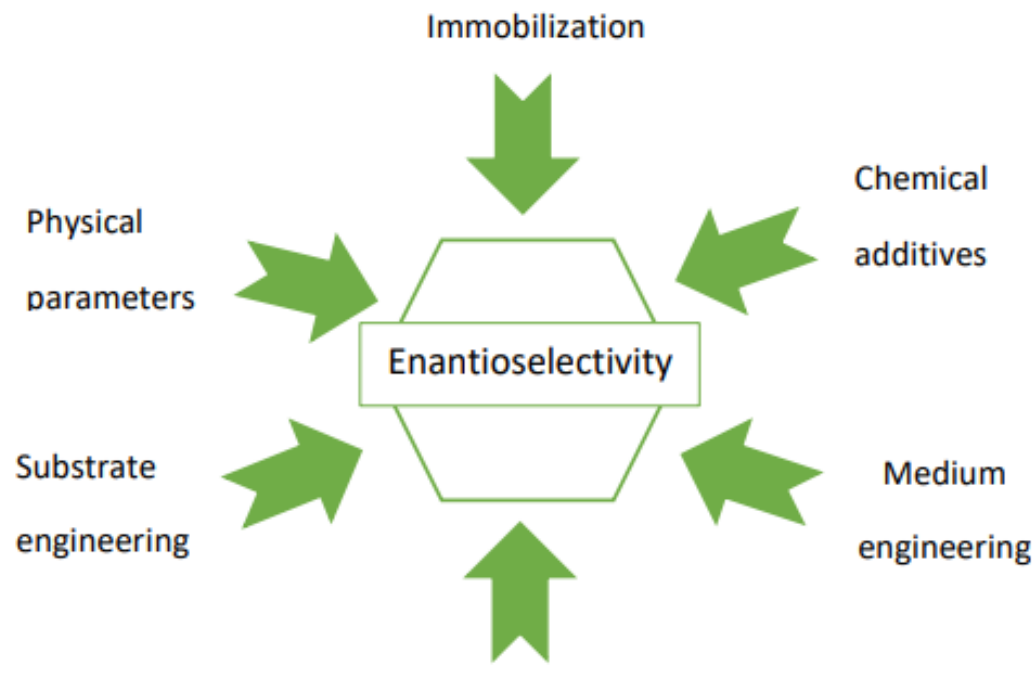

Cultivation

Scheme 1. Simple methods to improve the enantioselectivity of the biocatalytic reaction.

Such an approach enables the improvement of both the enantioselectivity as well as the yield of the reaction.

It is recommended to check several methods and their combinations in order to obtain the desired and the best enantioselectivity for a reaction.

This article is focused on a review of the most commonly applied simple modifications that lead to the desired pure enantiomers of products. Biotransformation protocols were chosen with regard to different types of biocatalyst, reaction, and reagent features. The above-mentioned manipulations provide the best results in cases involving the kinetic resolution of racemic mixtures of chiral substrates or reduction reactions of prochiral ketones; therefore, the examples presented in this article were limited to these two approaches.

\section{Whole-Cell Biocatalytic Synthesis of Chiral Derivatives-Main Strategies}

Optically pure alcohols, amines, etc., are applied as building blocks for the synthesis of chiral derivatives for diverse applications, e.g., pharmaceuticals, agrochemicals, flavors, and other applications [6]. The achievement of chiral compounds through traditional synthetic methods is usually associated with high costs, which is why new, cheaper, and environmentally friendly methods are under consideration. The most effective route for obtaining chiral products using whole cells of the biocatalyst are based on the kinetic resolution of racemic mixtures and on the asymmetric reduction of prochiral ketones [7]. Asymmetric bioreduction in particular seems to be an attractive alternative to traditional 
chemical methods due to the possible $100 \%$ efficiency that can be obtained for processes carried out under mild conditions.

\subsection{Asymmetric Bioreduction}

The use of whole-cell biocatalysts with reductase activity for the reduction of prochiral ketones enables the acquisition of enantiomerically pure alcohols of various structures. Depending on the applied biocatalyst or the structure of the substrate, bioreduction may be carried out in accordance with Prelog's rule [8] or in an anti-Prelog manner (Figure 1). In the first case, insertion of the hydride occurs on the Re face of the reduced ketone and the enantiomer of the corresponding alcohol is obtained as a product $S$. On the other hand, proton transfer according to anti-Prelog rules results in $R$ alcohol formation [9].

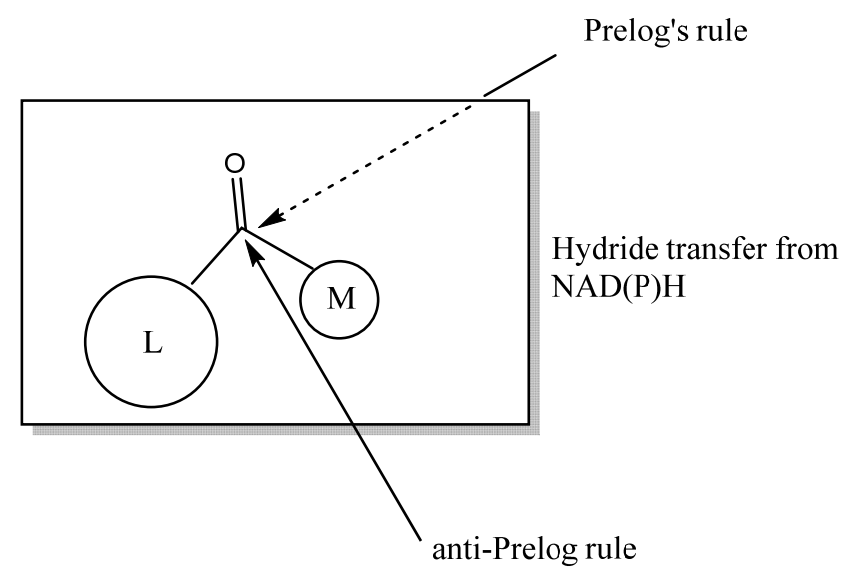

Figure 1. Hydride transfer according Prelog's and anti-Prelog rules (L, large group; M, medium group).

However, whole-cell-mediated biotransformations can exhibit noncomplete stereoselectivity, which results directly from the nature of applied living catalysts. The reason for this may be the presence of many enzymes with different stereoselectivities active toward the particular substrate(s) or, less often, the bioreaction can be catalyzed by a single enzyme that has noncomplete stereoselectivity.

By changing the structure of the substrate, activating or disactivating some dehydrogenases or ketoreductases by simple manipulation of the reaction medium or of the form of a biocatalyst, a real impact on the enantioselectivity of the bioreduction process can be achieved.

\subsection{Kinetically Controlled Resolution of Racemic Mixture}

Kinetic resolution of racemic mixtures through the use of whole cells of microorganisms can be conducted using either the hydrolytic activity of enzymes produced by biocatalyst cells or their oxidative activity. In both cases, the method is based on the increased affinity, and thus the faster conversion, of one of the enantiomers of the substrate (one chiral center), while the other does not relieve the reaction or is only slightly transformed. Depending on the type of biocatalyst activity, the selectivity of the reaction can be expressed in various ways. Hydrolysis reactions most often occur with the participation of lipases or esterases and, in these cases, the stereoselectivity of the reaction strongly depends on the structure of the substrate and its match with the enzyme binding pocket. According to Kazlauskas' rule [10], the $R$-enantiomer reacts faster for acylated substrates with small and large substituents in the molecules and $R$ alcohol is formed as a result [11]. As in the case of bioreduction, in the processes catalyzed by hydrolases it is also possible to control the stereoselectivity of the reaction, both through substrate engineering, optimizing the reaction environment, as well as by manipulating the activity of the biocatalyst, both at the culture stage (e.g., using inducers) and/or through the immobilization process.

Racemic mixtures of alcohols or amines can also be subjected to a biooxidation process based on the activity of oxidoreductases. The process can be realized with the participation 
of both dehydrogenases and oxidases. Similarly to dehydrogenases, oxidases are characterized by a chiral active site and, therefore, high enantioselectivity [12]; whole cells with oxidoreductase activity can thus be successfully used in kinetic resolution processes.

As mentioned in the Introduction, both the activity and the enantioselectivity of the whole cell biocatalyst may change depending on the applied reaction parameters, which enables the control of the course of the reaction and acquisition of the desired product with high yield and enantiomerical purity. The condition for the development of an effective process is the appropriate optimization of both the biocatalyst form and the reaction medium, as well as other physicochemical factors, such as time, temperature, and $\mathrm{pH}$. For biotransformations, in particular, the parameters should be selected individually depending on the type of process-hydrolysis, reduction, or oxidation. The applied modifications may influence the activity of the biocatalyst in various ways; for example, by inducing or inhibiting the activity of certain groups of enzymes or, as in the case of dehydrogenases, reducing the activity of the available variants with a specific enantioselectivity. In some cases (e.g., immobilization), the observed change in enantioselectivity may be a result of the deactivation of enzymes associated with cell membranes or an increase in the permeability of cell membranes, achieved with, for example, eutectic solvents. Simple methods that can affect the enantioselectivity of the reaction are presented below, along with selected examples of the reactions where they have been applied.

\section{Modifications of the Cell Activity}

The search for a biocatalyst with an appropriate level of activity is one of the most difficult stages in the development of a biotransformation process. Quite often, a selected biocatalyst, despite its general ability to catalyze a specific type of reaction, may be characterized by poor enantioselectivity, which makes it useless in obtaining optically pure chiral compounds. Sometimes, to change the enantioselectivity of the enzymes involved in the catalytic process, it is enough to alter simple parameters, such as the medium type, culturing time, or the status of the viable cells, by introducing appropriate pre-incubation steps.

\subsection{Biocatalyst Cultivation}

Proper selection of the culture medium is often a key step in obtaining a biocatalyst of the desired activity. Cell growth and development, including the increase of enzymatic activities, is guaranteed by the access to essential nutrients. Different microorganisms have different preferences for the optimal source of carbon, energy, nitrogen, and other biogenic elements. Media composition is a crucial parameter influencing the activation of different metabolic pathways and, thus, inducing enzymes of various desired activities. Culturing time is also an important matter, considering its effect on the microbes entering in the particular growth phases, which result in the expression of varied enzymatic activities. Another way of obtaining a biocatalyst with appropriate activity, including stereoselectivity, is microorganism cultivation under conditions that limit the access to some of the factor, necessary for viable cells, such as light for photosynthetic organisms [13] or oxygen for aerobic ones. This may also reduce the activity of oxygen-dependent enzymes, e.g., oxidases or oxygenases. In the case of photobiocatalysts, the light limit can trigger specific enzymes; for example, enzymes of the dark phase of photosynthesis [13]. Very often, a preferred way to increase the desired enzymatic activity, especially lipolytic activity, is to supplement the cultivation medium with appropriate inducers (e.g., vegetable oils) that enable the increase of the efficiency of the synthesis of enzymes of a specific selectivity [14].

\subsection{Incubation of Biocatalyst under Starvation Conditions}

The incubation of microbial cells under conditions that limit nutrients triggers changes in metabolic pathways. This results in the activation of specific degradation systems or processes related to secondary metabolism. Furthermore, these can induce the synthesis of enzymes of specific activities or activate the transport systems involved in taking up resources from the environment in order to fill up the missing biogenic nutrients. In the 
initial stage, microbes use the materials stored within the cells; then, if the starvation conditions are prolonged, they are forced to use every available source of nutrients-for example, xenobiotics present in the biotransformation medium. However, it should be remembered that the starvation stage should be selected individually according to the type of biocatalyst and the substrate in order to precisely achieve the desired purpose. Wrong process parameters can activate other groups of enzymes than those expected, which can interfere with a process in an adverse way. In cases of xenobiotics of particular biological activities—such as phosphonates derivatives, known for their inhibition properties towards various enzymes-it is sometimes necessary to combine approaches to succeed in obtaining the desired products. The transformation of phosphonate derivatives containing a heteroatom in the molecule, as described in a previous study, may serve as an example. In this case, the yeast's biomass (Rhodotorula mucilaginosa) was produced on potato dextrose broth (PDB, commercially available or handmade) medium or yeast universal medium (YM, 72 or $120 \mathrm{~h}$ ), and then the starvation step was introduced ( $24-48 \mathrm{~h}$ ). Such a biocatalyst was able to catalyze the stereoselective oxidation (kinetic resolution based on oxidative deamination) of one of the isomers of the initial racemic mixtures of 1-amino-1-(3-thienyl)methylphosphonic acid and 1-amino-1-(4-imidazole)methylphosphonic acid (Table 1), enabling the acquisition of the $S$-isomer of an adequate product, with enantiomerical purity up to $>99 \%$ and $95 \%$ e.e., respectively [15].

Table 1. Kinetically controlled resolution of racemic mixture of heterocyclic phosphonates with $R$. mucilaginosa assistance. Based on [15] with permission; copyright BioMed Central Ltd 2021.

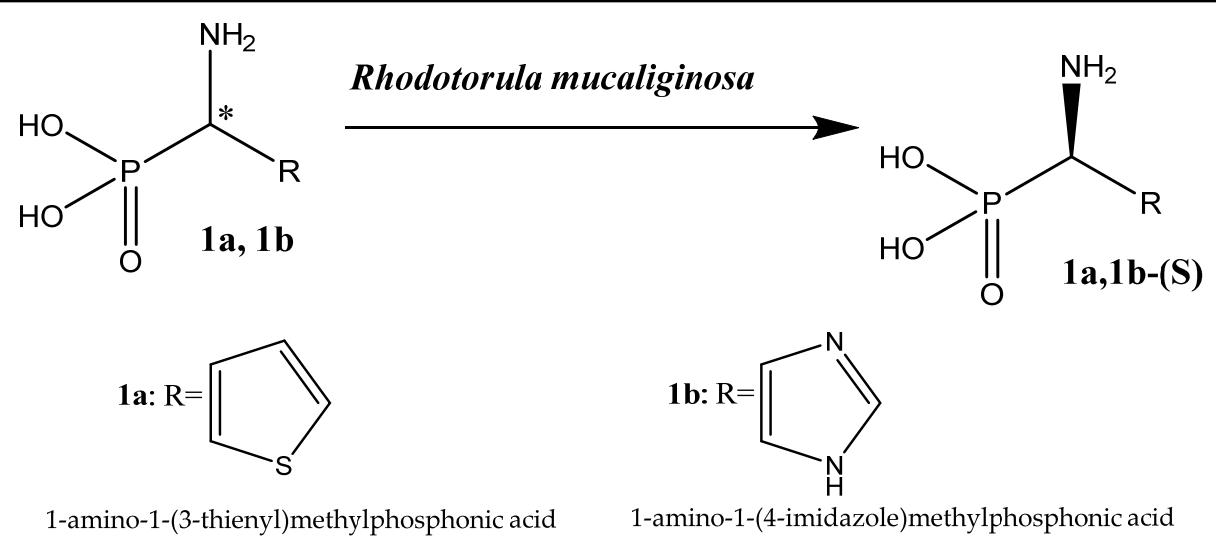

\begin{tabular}{|c|c|c|c|c|}
\hline Substrate & $\begin{array}{l}\text { Cultivation } \\
\text { Condition }\end{array}$ & $\begin{array}{c}\text { Biotransformation } \\
\text { Time (h) }\end{array}$ & $\begin{array}{l}\text { Starvation } \\
\text { Period (h) }\end{array}$ & $\begin{array}{c}\text { Enantiomeric * } \\
\text { Excess (\%) }\end{array}$ \\
\hline \multirow{6}{*}{$1 \mathrm{a}$} & YM (72 h) & 72 & 0 & 33 \\
\hline & PDB (120 h) & 24 & 0 & 94 \\
\hline & PDB (120) & 24 & 24 & 96 \\
\hline & PDB2 (120) & 24 & 0 & 39 \\
\hline & PDB2 (120) & 24 & 48 & $\geq 98$ \\
\hline & PDB2 (120) & 48 & 48 & $\geq 99$ \\
\hline \multirow{5}{*}{$1 b$} & YM (72) & 72 & 0 & 33 \\
\hline & PDB (72) & 72 & 0 & 32 \\
\hline & PDB (120) & 24 & 0 & 92 \\
\hline & PDB (120) & 24 & 48 & 95 \\
\hline & PDB2 (120) & 24 & 48 & 93 \\
\hline
\end{tabular}

* The bioconversion yield is related to the obtained e.e.-for pure enantiomer synthesis, the yield is $100 \%$. 
For both cases, the effect of biotransformation was in correlation with the longer cultivation time (5 days) and the following starvation period. It is quite possible that under such conditions the activation of enzymes capable of instigating more effective degradation processes occurs-for example, amino acid oxidases and/or transaminasesenabling the use of the available source of biogenic elements. According to the observations of the authors of the study, R. mucilaginosa cultured on PDB medium manifested better biocatalytic abilities for stereoselective oxidation of phosphonates than that cultivated on YM. Transformation of both exemplary substrates by yeast biomass obtained from YM led to products of low enantiomeric purity (33\% e.e.). Interestingly, slight differences in the reaction course were also noticed when potato medium was used for cultivation purposes. The thienyl derivative was more efficiently transformed after growing the biomass in a hand-made medium (98-99\% e.e.) compared to the imidazole derivative where the reverse trend was noticed (Table 1). The time of the starvation period and the biotransformation itself were also of great importance for the enantiomeric purity of the obtained products. For the selective resolution of the racemic mixture of the thienyl derivative, $48 \mathrm{~h}$ was the optimal period both for starvation and biotransformation. In the case of the imidazole derivative, the best periods were 48 and $24 \mathrm{~h}$, respectively [15].

Similarly, microorganism cultivation on different media, by applying pre-incubation under conditions of limited access to nutrients $[14,16,17]$ or changing the biotransformation time or the composition of the biotransformation medium (e.g., chemical additives, discussed later), results in an increase of the enantioselectivity of the biotransformation of other phosphonate derivatives and directs the process to the synthesis of only one enantiomer of a given compound.

\subsection{Whole-Cell Biocatalyst Immobilization}

The most common methods of modifying the catalytic properties of biocatalysts are immobilizations. Both whole cells and isolated enzymes can be modified by adsorption to a carrier, entrapment, encapsulation, cross-linking, or the use of covalent attachment of the biological material to the support [18]. The advantages and disadvantages of this process depend on the selected immobilization method. For example, covalent immobilization may interfere with the tertiary structure of the protein and negatively affect the enzymes activities. On the other hand, the use of weak interaction, as in adsorption procedures, can result in the biocatalyst being leached from the carrier surface [19]. This type of biocatalyst modification may have a real effect on selectivity by excluding some of the enzymes, e.g., those attached or anchored to cellular envelope. Therefore, in each case, the method of immobilization must be selected individually in accordance with the origin of the biocatalyst and the process parameters. Whole cells of the biocatalyst are most often modified by adsorption, entrapment, or encapsulation.

The various immobilization methods and selected examples of their effects on the enantioselectivity of the reaction are described below.

\subsubsection{Adsorption on a Carrier}

This is the simplest and most cost-effective method of immobilization. There are several types of bindings that allow biocatalyst attachment to exert support, such as hydrophobic and van der Waals interactions or hydrogen and ionic bonds [20]. Due to the weakness of such bonds, the biocatalyst is often leached from the support surface. Unfavorable reaction factors, such as temperature or $\mathrm{pH}$, may destabilize such constructs.

The unquestionable advantage of this type of immobilization is the possibility of using a wide variety of simple and cheap carriers, both inorganic (e.g., silica gel) and organic. These latter can be natural, like chitosan, starch, and cellulose, or synthetic, like polyurethane, polypropylene, or silicones [21]. Basic supports can also be chemically modified, which additionally increases the possible applications.

Most of the scientific papers that describe the use of adsorption as the only method of improving the biocatalytic properties of a microorganism are more than 10 years old. Some 
even date back to the 1980s. Currently, a combination of several methods is usually used to achieve the best possible reaction results [22].

\subsubsection{Entrapment}

Recently, immobilization by entrapment of the whole-cell biocatalyst has become the most frequently used method when the purpose of the reactions is to obtain one of the enantiomers in optically pure form [23]. The most conservative approach, in terms of the overall activity of the biocatalyst, is entrapment in the polymer network using non-covalent interactions [24]. Materials like polyacrylamide, collagen, alginate, agar, and gelatin are applied as a matrix [25]. The biocatalyst is separated from the reaction environment, which ensures protection against the harmful effects of the medium. The diameter of the carrier pore must be smaller than the diameter of the trapped biocatalyst in order to prevent catalyst escape from the support structure. Unfortunately, this also limits the size of the reactants [19]. Such immobilization affects the enantioselectivity through the moderation of the selectivity of the transport across the cell envelope, which is in direct contact with the entrapped material.

\subsubsection{Encapsulation}

Encapsulation can be defined as the closing of the biocatalyst in small capsules. As a result, the biocatalyst is protected and stabilized and its catalytic properties can be improved $[18,26]$. Surrounding the microbial cells with a semi-permeable polymeric matrix enables the physical separation of the cells from the external environment but also protects the internal microenvironment, ensuring that it is suitable for maintaining the activity of the biocatalyst. This technique has found applications in various biotechnological processes, such as probiotic encapsulation in food industries and in biotransformation and fermentation processes [27]. This method of biocatalyst immobilization may cause some problems in mass transport; therefore, both the type of carrier and its concentration should be matched adequately to the type of biocatalyst and to the structure of the substrate.

\subsubsection{Immobilization as a Factor Altering the Course of the Reaction-Examples}

One example of improving biocatalyst enantioselectivity by immobilization that can be cited is the enantioselective conversion of racemic sotalol (Figure 2$)$ to $(R)-(-)$-sotalol by whole-cell biocatalysts (fungal and bacterial) immobilized via the alginate entrapment method [28]. For all tested microorganisms, the immobilized biocatalysts were characterized by higher enantioselectivity compared to free cells. The increase in the enantioselectivity (E) after biomass immobilization in an alginate matrix was highest, in comparison to free cells, for Rhodococus erythropolis and Aspergillus niger: from $\mathrm{E}=10.34$ (82.37\% e.e.) to $\mathrm{E}=55.87$ ( $96.48 \%$ e.e.) and $\mathrm{E}=7.05$ (75.16\% e.e.) to $\mathrm{E}=53.34$ ( $96.45 \%$ e.e.), respectively [28]<smiles>CC(C)NCC(O)c1ccc(NS(C)(=O)=O)cc1</smiles>

Figure 2. Structure of racemic mixture of sotalol. Reprinted with permission from [28]; copyright Indian Pharmaceutical Association 2018.

Aspergillus niger free mycelium catalyzed the enantioselective conversion of racemic felodipine (Figure 3) to (S)-(-)-felodipine with an enantiomeric excess of $81.59 \%$ and a poor enantiomeric ratio of $\mathrm{E}=9.87$. These were not satisfactory results. Improvement was achieved by performing the reaction with Aspergillus niger trapped within calcium 
alginate. This approach resulted in acquisition of (S)-(-)-felodipine of high optical purity and enantiomeric ratio (98.27\% e.e., $\mathrm{E}=114.56)$ [29].<smiles>CCOC(=O)C1=C(C)NC(C)=C(C(=O)OC)[C]1c1cccc(Cl)c1Cl</smiles>

Figure 3. Structure of racemic felodipine.

Another example involved the use of Aspergillus niger and Escherichia coli for enantioselective resolution of $(R, S)$-carvedilol (Figure 4$)$ to $(\mathrm{S})$-(-)-carvedilol. The enantiomeric excess was $82.13 \%(E=10.9)$ and $76.07 \%(E=7.36)$, respectively. The biocatalyst modifications by cell entrapment through the use of alginate increased the enantioselectivity of the reaction for both strains. The optical purity and enantiomeric ratio were increased for both A. niger (e.e. $98.86 \%, \mathrm{E}=174.44$ ) and $E$. coli. (e.e. $98.10 \%, \mathrm{E}=104.26$ ) [30].<smiles>COc1ccccc1OCCNCC(O)COc1cccc2[nH]c3ccccc3c12</smiles>

Figure 4. Structure of $(R, S)$-carvedilol.

In some cases, the free biocatalyst delivers products of maximal optical purity but the efficiency is not sufficient. Such cases require modifications and immobilization is often the method of choice. It is important to choose the method that does not deteriorate the optical purity of the product. This was observed for Alcaligenes faecalis W10, which exhibits nitrilase activity and in the form of free cells was able to catalyze the hydrolysis of racemic mandelonitrile to $(R)-(-)$-mandelic acid $(R-\mathrm{MA})$ with perfect enantiomeric excess (e.e. $>99 \%$ ) [31]. Employing this microbe in a more extensive process required Ca-alginate entrapment. This allowed the use of immobilized A. faecalis ZJUTB10 (genetically modified W10) cells in an integrated bioprocess for the production of $(R)-(-)$-mandelic acid of the same high optical purity (e.e. $>99 \%$ ). This seems promising for use in large-scale industrial processes (Scheme 2) [32].<smiles>N#CC(O)c1ccccc1</smiles>

Scheme 2. Enantioselective hydrolysis of $(R, S)$-mandelonitrile to $(R)-(-)$-mandelic acid and the unreacted (S)-(+)-mandelonitrile. Reprinted with permission from [32]; copyright American Chemical Society 2013. 
The study by Żymańczyk-Duda et al. can be cited as confirmation of the beneficial effect of immobilization on the enantioselectivity of the biocatalytic reaction [33]. Penicillium funiculosum immobilized onto polyurethane foams in a simplified flow reactor system enabled effective enantiomer resolution (100\% e.e. for (S)-1-amino-2-methanepyridinephosphonate) by oxidative deamination (Scheme 3 ) and increased the scale of the process to an $11.2 \mathrm{mM}$ solution of the substrate (the maximal concentration of substrate for nonimmobilized cells was $1.34 \mathrm{mM}$ ). Such a good result was possibly due to the minimization of the toxic effect of the substrate on the cells by the protection implemented by the carrier used in the immobilization process. Moreover, the removal of the xenobiotic molecules from the cell surface by forced flow of the substrate solution in the reactor was beneficial for the process. The increase in the enantiomeric purity of the product (from 0 to $100 \%$ e.e.) can be explained by either the different affinities of the substrate enantiomers to the oxidases of the opposite enantioselectivity, resulting in a faster elution of one of the enantiomers, or by the destruction of one isoform of the enzymes bounded to the cell envelope during the immobilization process. The authors indicated that oxidases were the main enzymes responsible for the observed transformation of the phosphonate derivative. However, it should be taken into consideration that, under starvation conditions, other enzymes-e.g., transaminases of opposite selectivity - can be also activated and engage in the process.<smiles>N[C@H](c1cccnc1)P(=O)(O)O</smiles>

1-amino-1-(3'-pyridyl)methylphosphonic acid<smiles>N[C@H](c1cccnc1)P(=O)(O)O</smiles>

S-1-amino-2-methanepyridinephosphonate<smiles>O=C(c1cccnc1)P(=O)(O)O</smiles>

1-oxo-1-(3'-pyridyl)methylphosphonic acid

Scheme 3. Enantioselective biotransformation of 1-amino-1-(3-pyridyl)methylphosphonic acid. Based on [33] with permission; copyright Elsevier Inc. 2019.

The most representative example of the influence of a particular immobilization technique on the stereoselectivity of the process can be found in the study conducted by Lubiak-Kozłowska et al. [17], in which the appropriate selection of the carrier made it possible to reverse the enantioselectivity of the process. Fresh $R$. mucilaginosa yeasts cells, after a $24 \mathrm{~h}$ starvation period, catalyzed the oxidative deamination of a racemic mixture identical with the above 1-amino-1-(3'pirydyl)methylphosphonic acid with $R$ enantiopreference, allowing the synthesis of an optically pure $S$ enantiomer with a50\% conversion degree. On the other hand, the immobilization of the same microorganism in a $4 \%$ agar-agar solution made it possible to manufacture the second pure $R$ enantiomer (50\% conversion degree). This is direct evidence that manipulation of simple parameters can activate enzymes of different enantiospecificities and consequently enables stereocontrol of the biocatalytic reactions. 


\section{Selected Reaction Parameters}

Biocatalysts usually work under individually adjusted conditions. These mainly include temperature [34], $\mathrm{pH}$, reaction time, agitation speed, and the different co-solvents or additives added to the reaction medium [3,4]. Unfortunately, it is not always possible to ensure optimal operating conditions for biocatalysis, as this may adversely affect the enzyme activities or microbe cells and reagents. It can also be difficult due to the limitations of laboratory equipment. Another problem may be the high cost of maintaining optimal reaction conditions in a large-scale process, making it unprofitable.

Particular process conditions should be selected according to the type of reaction and the optimal parameters for biocatalysts. There are seven classes of enzymes. Each class has a different Enzyme Commission (EC) number and contains enzymes that catalyze a particular type of reaction. These include oxidoreductases (EC 1), transferases (EC 2), hydrolases (EC 3), isomerases (EC 4), lyases (EC 5), ligases (EC 6) [35], and translocases (EC 7). Depending on whether is the process concerns, for example, hydrolysis or oxidation and reduction, different parameters should be selected. The conditions must also be optimal for the structure of the enzyme. Too low a temperature can deactivate the enzyme, while too high a temperature or $\mathrm{pH}$, or overly rapid mixing, may degrade the tertiary structure of the protein [36]. These factors may also influence the viability of the microbial biocatalysts, knocking out the cells' enzymatic activities. Selected examples focused on the optimization of the conditions of enantiomer synthesis-oriented processes are presented below.

Enantioselectivity improvement was achieved in the deracemization of aliphatic $\beta$ hydroxy esters through optimized procedures carried out with different $\mathrm{pH}$ levels, reaction times, and co-solvents, employing Candida parapsilosis ATCC 7330 as the biocatalyst. Application of the Tris- $\mathrm{HCl}$ buffer $(\mathrm{pH}=8.5)$ in combination with acetone $(4 \%)$ and acetonitrile $(1 \%)$ instead of a water reaction medium resulted in an increase of the enantiomeric excess up to $69 \%$, in contrast to water mixed with acetone and acetonitrile in the same concentration as above, which resulted in product formation with $39 \%$ enantiomeric excess [37]. Alkaline $\mathrm{pH}$ favored the first step of deracemization; i.e., oxidation [38,39].

Optimal reaction parameters were also investigated for the stereoinversion of (S)-1(1-naphthyl)ethanol to (R)-1-(1-naphthyl)ethanol. The biomass of Candida parapsilosis was selected to catalyze the process and high enantioselectivity was achieved at temperatures ranging from $25{ }^{\circ} \mathrm{C}$ to $35{ }^{\circ} \mathrm{C}$ (e.e. $100 \%$ ). At $40{ }^{\circ} \mathrm{C}$, a drastic drop in enantioselectivity (e.e. $22 \%$ ) was observed. The maximal enantiomeric excess was noted at $\mathrm{pH}$ levels of 7 to 10 , although it was accompanied by decreases in the yield of the reaction. Therefore, a $\mathrm{pH}$ value of 7 proved to be optimal. Under the abovementioned conditions, the highest enantioselectivity of the catalysts was provided by the reaction lasting for $12 \mathrm{~h} \mathrm{[40].} \mathrm{In}$ another study, the microorganism Lactobacillus paracasei BD101 was used for the bioreduction of cyclohexyl(phenyl)methanone to (S)-cyclohexyl(phenyl)methanol with high enantiomeric excess [41]. At $\mathrm{pH}$ 6.0, the best values for enantiomeric purity reached up to $84 \%$ e.e. Above or below that $\mathrm{pH}$ value, the enantiomeric excess dropped down. This led to the conclusion that changes in $\mathrm{pH}$ strongly affect the three-dimensional structure of the enzyme by decreasing its activity [41,42]. Another parameter, agitation, was equally important in these experiments. The authors of [41] proved that high enantiomeric purity ( $99 \%$ e.e.) can be obtained with agitation not higher than $150 \mathrm{rpm}$. More vigorous mixing can adversely affect the activity of enzymes associated with the cell membrane, while overly slow mixing may in turn limit the availability of the substrate for the biocatalyst.

An intermediate applied in the production of the antiviral agent lamivudine, which is targeted for the treatment of hepatitis B virus and HIV infection, can be obtained through an enantioselective hydrolysis reaction catalyzed by Klebsiella oxytoca (Scheme 4). For this purpose, the selection of the following process conditions is crucial: $\mathrm{T}=30^{\circ} \mathrm{C}$ and $\mathrm{pH}$ 7.0. This ensures that a product of high enantiomeric excess (e.e. 99.9\%) is obtained [43]. 


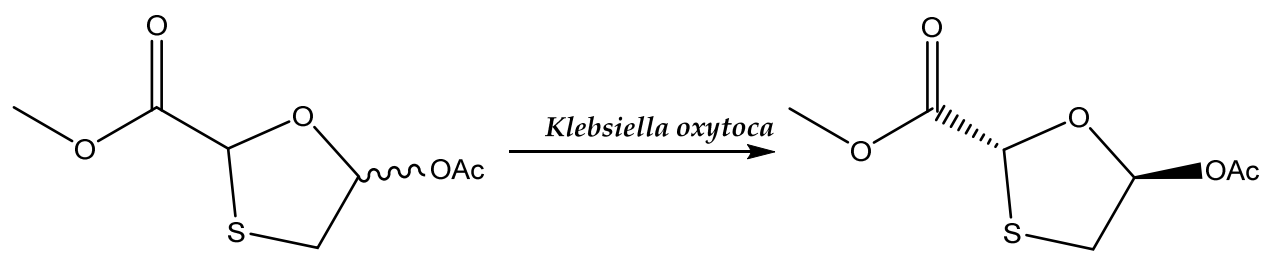

1,3-oxathiolan-5-ones

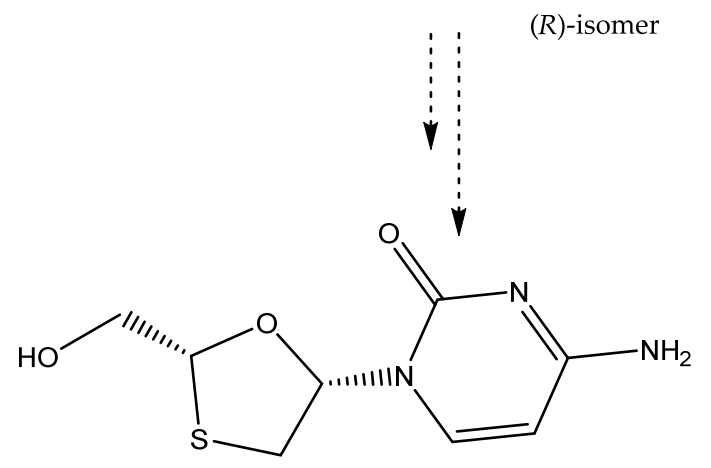

Lamivudine

Scheme 4. Enantioselective hydrolysis of 1,3-oxathiolan-5-ones for the production of lamivudine. Based on [43] with permission; copyright Elsevier Ltd. 2019.

Applications of biocatalysts for industrial purposes, which usually generate higher temperatures, require thermostable and resistant biomasses. As a consequence, much research has been focused on the evaluation of the stability of particular biocatalysts under higher temperatures [44]. One example relates to the next exemplary bioreaction. Thus, at a relatively high temperature $\left(45^{\circ} \mathrm{C}\right)$, it was possible to bioreduce ketoamide 4-oxo-4-[3-(trifluoromethyl)-5,6-dihydro-[1,2,4]triazolo[4,3-a]pyrazin-7(8H)-yl]1-(2,4,5-trifluorophenyl)butan-2-one (OTPP) to (S)-3-hydroxy-1-(3-(trifluoromethyl)-5,6dihydro-[1,2,4]triazolo[4,3-a]pyrazin-7(8H)-yl)-4-(2,4,5-trifluorophenyl)butan-1-one ((S)HTPP) (Figure 5) using a fungal strain identified as Rhizopus microsporus var. rhizopodiformis ZJPH1308. After $24 \mathrm{~h}$ of the reaction carried out in $45^{\circ} \mathrm{C}$ and with the presence of $15 \mathrm{mM}$ OTPP, it was possible to obtain (S)-HTPP of high optical purity (e.e. $>99 \%$ ) [45]. In this case, the duration of the process was the limitation factor. The enantioselectivity of the reaction increased for up to $48 \mathrm{~h}$ of the reaction, but further extension of the reaction time resulted in it decreasing.<smiles>O=C(C[C@@H](O)Cc1cc(F)c(F)cc1F)N1CCn2c(nnc2C(F)(F)F)C1</smiles>

(S)-HTPP

Figure 5. The structure of (S)-HTPP. Reprinted from [45] with permission; copyright Springer Science and Business Media 2016).

The next example-asymmetric reduction of acetophenone to (S)-1-phenylethanol by Candida zeylanoides $\mathrm{P} 1$-also shows that the incubation time should be kept maximum for up to $48 \mathrm{~h}$, allowing the achievement of e.e. of up to $90 \%$. The prolongation of reaction duration resulted in improvements in the reaction efficiency but also the diminishment of the 
enantioselectivity. After 96 h, the bioreduction efficiency was 97\%, while the enantiomeric excess was much lower (77\%). It can be concluded that, over time and through exposure to external factors, the biocatalyst loses its selectivity, perhaps due to the activation of enzymes of opposite enantioselectivity. In such cases, the incubation period should be adapted to the industrial purpose [46]. The optimization of the reaction conditions in one study enabled the reduction of the 4-nitroacetophenone to the corresponding $S$-alcohol on a gram scale ( $89 \%$ yield, $>99 \%$ e.e.) [46].

\section{Substrate Engineering}

In whole-cell biocatalysis, the substrate concentration can influence the stereoselectivity of bioreactions. It is known that an enzyme can exhibit perfect enantioselectivity as a result of precise non-covalent interactions between the substrate and the enzyme's binding pocket. However, in the case of whole-cell mediated processes, noncomplete stereoselectivity can be observed. As was mentioned above, there are two reasons for noncomplete reaction stereoselectivity. The first, connected with single enzyme involvement, is independent of substrate concentration because of the individual intrinsic properties (e.g., the 3D structure of the enzyme active site) of the enzyme. More often, noncomplete stereoselectivity is due to the activity of various enzymes of different stereoselectivities (and also opposite ones) in relation to the same substrate. In such cases, the increase of substrate concentration may negatively influence the reaction stereoselectivity-the substrate becomes more accessible for enzymes of lower specificity. Also, the manipulation of substrate concentration is all the more unsuitable because of the possible toxic effect of the non-physiological impact on the living cells.

Thus, selectivity can be achieved by improving the matching between enzyme and substrate by remodeling the substrate structure to ensure adequate interactions [47]. In recent years, the rational design of substrates has been successfully applied for lipases [48,49] and in bioreduction reactions [9]. In the case of bioreduction of substituted acetophenones, the presence of the group in the para position does not affect the selectivity of the reaction, but the electron-withdrawing substituent may cause a decrease in the efficiency of the process. In the case of aliphatic methyl ketones, increasing the alkyl group causes a decrease in both the conversion and optical purity of the products [9]. Transformation of $p$-bromoacetophenone can occur both according to Prelog's rule ( $S$-alcohol is obtained) and in the opposite way ( $R$-alcohol is formed), depending on the biocatalyst used. Rhodotorula rubra was able to reduce the mentioned substrate with high yield and enantiomeric excess, leading to the S-enantiomer (98\% and 99\%, respectively), while Geotrichum candidum reduced the same substrate to the $R$-enantiomer, obtained with $99 \%$ yield and 99\% e.e. [50]. Most of the known bioreduction reactions lead to S-alcohols according to Prelog's rule when the smaller substituent in the prochiral ketone has a lower priority in the Cahn-Ingold-Prelog rule (absolute configuration determination). It is possible to obtain $R$-alcohols, which are equally important building blocks in organic synthesis, with the use of microorganisms acting according to the anti-Prelog rule. Empedobacter brevis ZJUY-1401 is able to effectively reduce acetophenone derivatives with high purity (>99\% e.e.); however, some substituents, such as methyl, halogen, and alkoxes, reduce the activity and cause a decrease in conversion, probably as a consequence of steric hindrance [7]. Additionally, the localization of substituents at the aromatic ring strongly influences the activity of the biocatalyst. Transformation of the ortho- or meta-substituted derivatives requires longer reaction times and gives lower yields in comparison to para-substituted analogues. Knowledge about such dependencies enables the rational design of the substrate structure to obtain optically pure products with the highest efficiency.

\section{Various Solvents as Reaction Media}

Water is the natural enzyme environment. Unfortunately, most reactants are insoluble or instable in aqueous media. As a result, it is not possible to proceed with reactions and synthesize the desired products. One solution to this problem is the use of non-aqueous 
media or media with low water content. Considering the large scale of industrial processes, which consume large amounts of water, and due to the limited resources of fresh water, it is preferable to search for new reaction media. The media most commonly used as reactions environments are organic solvents, deep eutectic solvents, ionic liquids, and supercritical fluids [51-53].

\subsection{Organic Solvents}

Organic solvents are the most widespread, most common, and longest used nonaqueous solvents in biocatalysis. However, in the 1980s, the success of biocatalysis in non-aqueous solvents was not fully accepted. This changed after deep studies on the correlations between the catalytic capacity of enzymes and the parameters of organic solvents were conducted. The rules for the appropriate selection of the solvent, and thus the optimization of the biotransformation conditions, are based both on previous reports from the literature and on knowledge of the properties of the solvent itself [54]. The usability of chemical solvents for biocatalytic goals is evaluated by the logarithm of the partition coefficient, $\log p$, determining the solvent polarity. The efficiency of biocatalysis in organic solvents is low in polar solvents $(\log p<2)$, moderate in solvents with $\log p$ between 2 and 4 , and high in solvents with $\log p>4$. It has been found that the relationship between the polarity and the activity of a biocatalyst is associated with the ability of organic solvents to disturb the essential water layer necessary for the stability of the biocatalyst [55]. Understanding these rules makes it possible to successfully carry out enzymatic processes in environments including an organic solvent.

It is often mentioned that organic solvents are harmful to the environment. However, even among such solvents, eco-friendly ones can be distinguished [56]. Organic compounds can be also used as co-solvents positively influencing the parameters of the process. By increasing the solubility of substrates or influencing the permeability of cell membranes, contact between the biocatalyst and starting compound is facilitated. One example of this kind of reaction is the kinetic resolution of 2-epoxy hexane by Rhodotorula glutinis cells (Scheme 5), which has been performed in organic solvents. The first approach assumed the use of n-dodecane and 1-heptanol separately as solvents and gave unsatisfactory results. In the case of n-dodecane, 59\% enantiomeric excess (with $E=14$ ) was achieved, and in the case of 1-heptanol, no reaction was observed. In contrast, the application of the reaction mixture containing $\mathrm{n}$-dodecane and 1-heptanol at different concentrations $(0.017$ M, $0.034 \mathrm{M}$, and $0.051 \mathrm{M}$ ) allowed the obtainment of a product of high optical purity: the $R$-enantiomer was synthesized with e.e. of up to $99.9 \%$ and $\mathrm{E}>100$ [57]. Perhaps the mixture of these two solvents provided the appropriate polarity to maintain the high activity and stereoselectivity of the hydrolase involved in the process. The addition of a small amount of 1-heptanol can act as a permeabilization factor, while a single-phase reaction medium can lead to lysis of the biocatalyst cells.

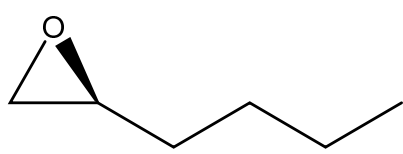

(R)-1,2-epoxyhexane

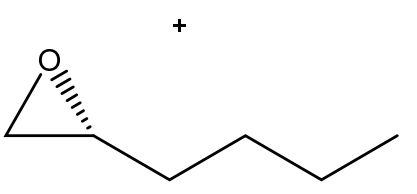

(S)-1,2-epoxyhexane

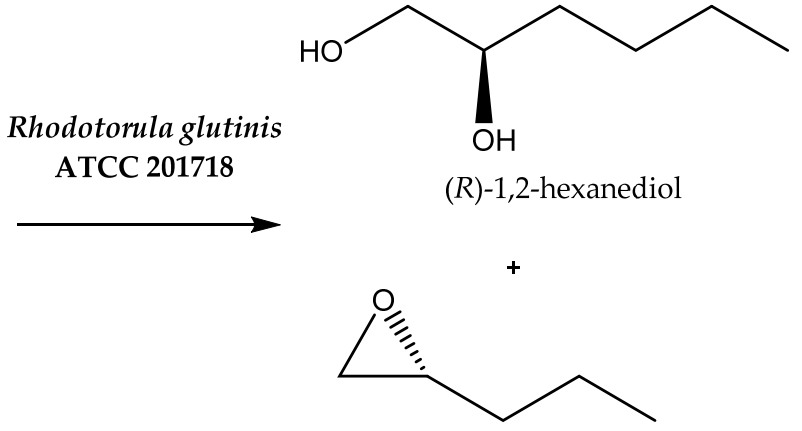

(S)-1,2-epoxyhexane

Scheme 5. Enantioselective hydrolysis of rac-1,2-epoxyhexane. Reprinted from [57] with permission; copyright Society of Chemical Industry 2013. 
Two-phase buffer/organic solvent systems have also been used and they achieved the best possible reaction results. As an example, the resolution of racemic 1-phenyl-1,2ethanediol to (S)-1-phenyl-1,2-ethanediol catalyzed by Kurthia gibsonii SC0312 (Scheme 6) has previously been performed in buffer and a product with high enantiomeric excess (e.e. $99.9 \%)$ and enantiomeric ratio $(\mathrm{E}=133)$ was formed. However, the creation of a dibutyl phthalate/buffer 1:1 $(v / v)$ system made it possible to improve the enantioselectivity level to $E=208$. This could have been caused by the influence of organic solvents on the permeability and integrity of the biocatalyst cell membrane [58]. The second reason for the increase in enantioselectivity may have been connected with the improved solubility of the reagents in the organic layer, which could have been a reason for the escape of the products from the biocatalyst environment, moving the reaction balance toward the product formation. Thus, this can accelerate the oxidation of the $R$-enantiomer of racemic alcohol.

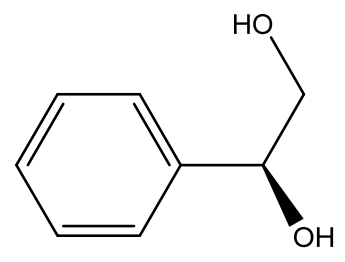

(S)-1-phenyl-1,2-ethanediol

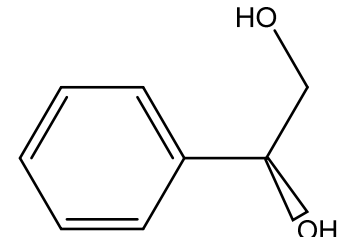

(R)-1-phenyl-1,2-ethanediol
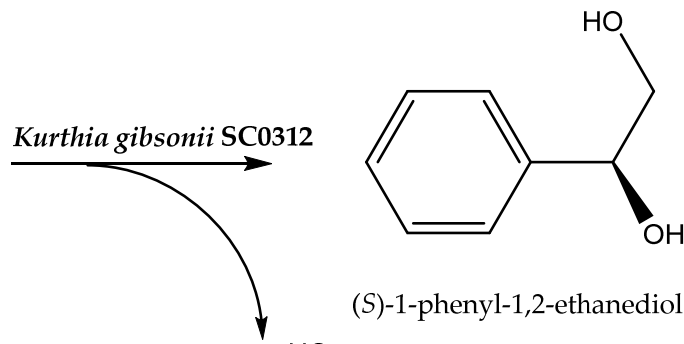

(S)-1-phenyl-1,2-ethanediol

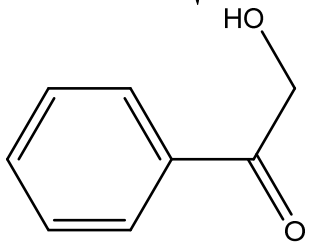

2-hydroxyacetophenone

Scheme 6. Asymmetric biooxidation of racemic 1-phenyl-1,2-ethanediol. Reprinted from [58] with permission; copyright Elsevier B.V. 2019.

\subsection{Ionic Liquids (ILs)}

Recently, ionic liquids have frequently been used in biocatalytic processes due to their unique properties, such as nonvolatility, nonflammability, and excellent chemical and thermal stability. The first records about the discovery of ionic liquids date to 1914 [59]. According to the principles of green chemistry, they are defined as green solvents $[52,60]$. Thanks to their physical and chemical properties, like their structure combinations, nontoxicity, recoverability, recyclability, efficiency, and biological activity [61-63], they have found many applications in various industries [64]. Literature data made it possible to conclude that they are often used as media in enantioselective biocatalysis. Selected ways of using them as enantioselectivity improvers are described below.

Ionic liquids added to the reaction medium can solve problems encountered during the biotransformation, such as those relating to enzyme activity or the stability of substrates and products, and their presence can have also a positive effect on the enantioselectivity of the processes. Such a solution has been implemented in a reaction with Cryptococcus sp. M93, employed to obtain (S)-(4-chlorophenyl)-(pyridin-2-yl)methanol ((S)-CPMA) (Figure 6), an intermediate in the production of the antiallergic drug Betahistine. This compound is produced by the bioreduction of (4-chlorophenyl)-(pyridin-2-yl)methanone (CPMK). The problem with obtaining an enantiomerically pure product was defined as the coordination effects of 2-pyridine and the substituents. It was important to direct the reaction to the desired product. The use of the hydrophilic ionic liquid [C2mim][(MeO)HPO2], which may affect the activity of intracellular ketoreductases, resulted in the obtainment of a product of perfect enantioselectivity (e.e. 99\%) and high efficiency (89\%) [65]. 
<smiles>O[C@H](c1ccc(Cl)cc1)c1ccccn1</smiles>

S-CPMA

Figure 6. Structure of (S)-CPMA. Reprinted from [65] with permission; copyright Elsevier B.V. 2017.

Addition (at 10\% $v / v)$ of a hydrophilic ionic liquid such as 1-(2'-hydroxyl)ethyl-3methylimidazolium nitrate has been effectively undertaken in the bioreduction of several aryl ketones and demonstrated high biocompatibility and increased the permeability of the cell membranes, which facilitated the reaction course. All the tested ketones, which had different substituents, were reduced with Acetobacter sp. to the corresponding $R$-alcohol with anti-Prelog enantiotopic selectivity and mostly with high enantiomeric excesses of up to $99 \%$ [66]. Additionally, as in the previously discussed case (see Section 5), the course of the bioreduction process was facilitated both by the type of substituent (electronwithdrawing groups, such as $-\mathrm{NO}_{2}$ or halogen) and its location in the aromatic ring (ortho position) [9].

Unfortunately, whole-cell biocatalysts often lose their activity when in direct contact with the ionic liquid used as the reaction medium. Therefore, two-phase systems are usually applied, in which isolated enzymes, mainly lipases or genetically modified microorganisms, work as biocatalysts $[67,68]$. For whole-cell-mediated reactions, ILs might affect both the enzyme activity bounded by/in cells and the cell structures. The harmful effect of ionic liquids on the integrity of the cell envelope and thus the activity of the whole-cell biocatalyst can be explained by possible electrostatic interactions between ILs and the cell-bounded protein, which may cause various structural changes, resulting in the variety in stability and activity of the biocatalysts [69].

\subsection{Deep Eutectic Solvents (DESs)}

Another type of solvent often used in biocatalytic reactions are deep eutectic solvents (DESs). Like ionic liquids, they also belong to the group of green solvents [60]. To be qualified to for inclusion in such a group of solvents, a solvent must be characterized by features such as nontoxicity, availability, low price, biodegradability, and recyclability [53]. All these advantages characterize DESs. Eutectics can be defined as homogeneous mixtures of at least two compounds. Together, they have a lower melting point than either of the substances separately. The eutectic point can be found where the molar ratio of the components shows the lowest melting point [70]. Due to their features, they are more often used in biocatalysis than other liquids. Selected examples of their use are described below.

Deep eutectic solvents are applied as the main solvents or co-solvents for both isolated enzymes and whole-cells biocatalysts. There are data showing that DESs increase the enantioselectivity of the reactions carried out by the most widely used yeast strain, Saccharomyces cerevisiae. Reduction of ethyl 3-oxobutanoate to ethyl 3-hydroxybutanoate catalyzed by whole-cell baker's yeast was performed in a cholinium-based DES. By adjusting the water content in the DES, it was possible to influence the enantiotopic selectivity of the process and, as a result, enantiomeric excess of the $S$-enantiomer of the product of up to $90 \%$ was achieved [71]. The appropriate ratio of solvents influences not only the enantiotopic selectivity of the reaction but also affects the final result, i.e., the type of $S$ - or $R$-enantiomer obtained. Thus, depending on the solvent (water or DES), opposite enantiomers were obtained during the reduction of ethyl acetoacetate catalyzed by baker's yeast (Scheme 7). Applying the pure water reaction medium and whole-cell biocatalysts resulted in the formation of an S-enantiomer of high enantiomeric purity (95\% e.e.), whereas using DES (choline 
chloride/glycerol) with a small addition of water (up to $20 \%$ ) led to an $R$-enantiomer that was also of high enantiomeric purity ( $95 \%$ e.e.). The described approach made it possible to obtain two different enantiomers of products with the use of the same biocatalyst [72]. One possible explanation for the observed effect may be the interaction of the DES with the components of the cells membranes of the biocatalyst, which may have resulted in the inactivation of membrane-bounded dehydrogenases of $S$ specificity, which would have enabled the expression of the activity of dehydrogenases of opposite enantioselectivity.

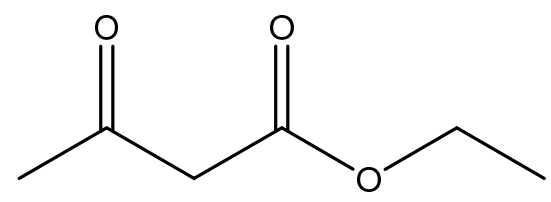

ethyl acetoacetate
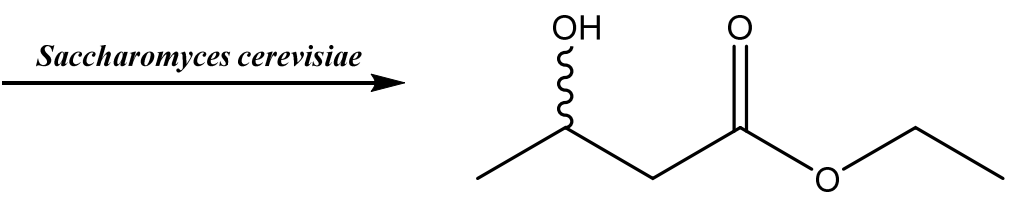

$R$ or $S$ enantiomer

Scheme 7. Bioreduction of ethyl acetoacetate. Reprinted from [72] with permission; copyright Wiley-VCH Verlag GmbH \& Co. KGaA, Weinheim 2014.

A similar effect of the impact of DESs on baker's yeast reduction of arylpropanones was observed in another study (Scheme 8). Furthermore, this time, the selection of the appropriate DES (choline chloride/glycerol) and the control of the water content in the mixture influenced the enantioselectivity of the reaction as well as the reversal of the preference for the $S$ - and $R$-enantiomer synthesis. Deep eutectic solvents with $10 \%$ or $20 \%$ water content had an impact on the synthesis of the $R$-enantiomer, with molar ratios of 95:5 and 91:9, respectively [73].

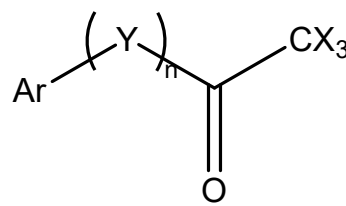

$\mathrm{X}=\mathrm{H}, \mathrm{F} ; \mathrm{Y}=\mathrm{CH}_{2} \mathrm{O}, \mathrm{CH}_{2} ; \mathrm{n}=0-2$

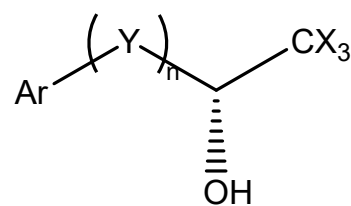

$(S)$

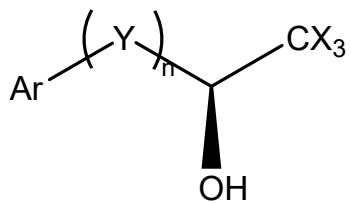

$(R)$

Scheme 8. Bioreduction of arylpropanones. Reprinted from [73] with permission; copyright Wiley-VCH Verlag GmbH \& Co. KGaA, Weinheim 2017.

Another study described how the bacterial whole-cell biocatalyst Acetobacter sp. CCTCC M209061 catalyzed the bioreduction of 3-chloropropiophenone to (S)-3-chloro-1phenylpropanol. The addition of DES in the form of choline chloride/urea ([ChCl][U]) $(5 \%$ $v / v)$ in the TEA-HCl buffer resulted in a high reaction efficiency with an ideal enantiomeric purity of the product (e.e. 99.9\%) within just $6 \mathrm{~h}$. This proves the high productivity of DES-enriched systems [74].

The next study described the use of Rhodococcus erythropolis XS1012 to reduce 3,5bis(trifluoromethyl) acetophenone to (S)-3,5-bistrifluoromethylphenyl ethanol ((S)-BTPE), an important intermediate in the pharmaceutical industry. The results of the reaction in phosphate buffer were unsatisfactory. Therefore, choline chloride/urea ([ChCl][U]) was added, which increased the permeability of the biocatalyst cell envelopes. It allowed synthesis of a product of high yield (91.9\%) and in enantiomerically pure form (e.e. $>99.9 \%$ ) [75].

\section{Natural Deep Eutectic Solvents}

Among the deep eutectic solvents, natural deep eutectic solvents (NADESs) can be distinguished. They include metabolites of plant origin, such as sugars or amino acids; hence the origin of the word "natural" [76]. They are introduced into reactions where the enantiomeric purity of the product is important. 
Although bacterial and fungal cell-mediated biocatalysis is the most widely known, plant cells can also act as useful complex enzymatic systems. Various kinds of NADESs have been applied as reaction media for the asymmetric reduction of 1-(3,4)-dimethylphenyl) ethenone to (S)-1-(3,4-dimethylphenyl)ethanol and (R)-1-(3,4-dimethylphenyl)ethanol catalyzed by carrot cells (Scheme 9). As in the case of traditional deep eutectic solvents, here also the use of an appropriate reaction medium controlled the direction of the selectivity of the reaction. The reduction carried out in water resulted in high enantioselectivity towards the $S$-enantiomer (e.e. 95.6\%); in contrast, the use of NADESs containing some water (up to $50 \%$ ) directed the process to the $R$-enantiomer (e.e. $32.66-75.27 \%$ ). The most promising for this purpose seemed to be the NADES consisting of choline chloride and xylose with a water content of $30 \%$ [77].<smiles>CC(=O)c1ccc(C)c(C)c1</smiles>

1-(3,4-dimethylphenyl)ethanone

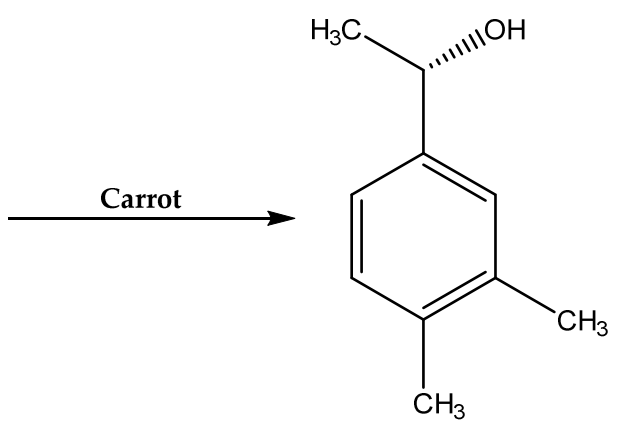

(S)-1-(3,4-dimethylphenyl)ethanol

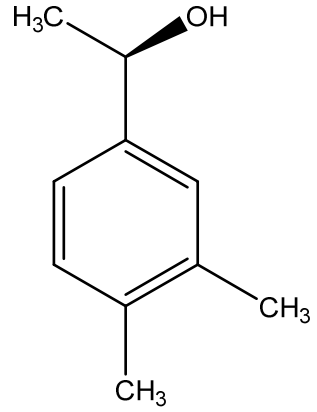

(R)-1-(3,4-dimethylphenyl)ethanol

Scheme 9. Asymmetric reduction of 1-(3,4)-dimethylphenyl)ethanone to (S)-1-(3,4-dimethylphenyl) ethanol and (R)-1-(3,4dimethylphenyl)ethanol. Reprinted from [77] with permission; copyright Elsevier Ltd. 2017.

\subsection{Supercritical Carbon Dioxide}

Another green solvent is supercritical carbon dioxide. This can be used to introduce a biocatalyst into the reaction mixture or to extract the reaction products, as well as for phase separation [78-81]. It works in biocatalysis as a medium, mostly for hydrolytic reactions catalyzed by lipases and proteases [82-86], but there is limited research data on its use to improve the enantioselectivity of reactions catalyzed by whole-cell biocatalysts.

The use of supercritical carbon dioxide, an unnatural solvent, as a reaction medium can unfortunately deactivate enzymes. Pressure is necessary to obtain a supercritical state, in which high density can inactivate enzymes or influence the transport of reagents through cell envelopes.

Therefore, there is a need to develop methods to stabilize the activity of whole cells; for instance, through a properly selected immobilization process. To take one example, the immobilization of Geotrichum candidum cells on water-absorbing polymer for the asymmetric reduction of aromatic ketones using supercritical dioxide as a reaction medium resulted in cells with high enzymatic activities and excellent enantioselectivities ( $>99 \%$ e.e.) [87].

\section{Chemical Additives as Modulators of Biocatalyst Activity}

Experimental approaches employing chemical additives as one of the biotransformation ingredients are commonly applied for a variety of different reaction types and biocatalysts and, therefore, such approaches are also used for microbial oxidoreductases. These are important tools for biocatalytic purposes, since the additives make it possible to obtain chiral secondary alcohols or amines. Enantiomerically pure secondary alcohols are valuable synthetic intermediates for the synthesis of compounds with various activities [88]. Enzymes involved in oxidation and reduction reactions depend on coenzymes. The most common coenzymes in these types of reactions are nicotinamide nucleotides $(\mathrm{NAD}(\mathrm{P}) \mathrm{H}$ or $\left.\mathrm{NAD}(\mathrm{P})^{+}\right)$. They enable the electron and proton flow in redox reactions, such as bioreductions, and they are necessary for the proper course of such reactions. However, the cost of 
exogenous nicotinamide coenzymes is quite high and can be a serious limitation of this enzymatic processes. Therefore whole-cell biocatalyst systems seem to be a better solution because they have their own effective systems of coenzyme regeneration. Data from the literature $[89,90]$ indicate that the addition of a catalytic amount of some low weight chemicals to the reaction media can affect dehydrogenase activity via the impact on the balance between the oxidized and reduced forms of coenzymes (Figure 7). These chemicals can act in two ways-as proton acceptors or donors interfering only with the cellular cofactor regeneration system, or they can affect the redox paths as substrates or intermediates, simultaneously employing the transformed substrate as a part of hydrogen flow.

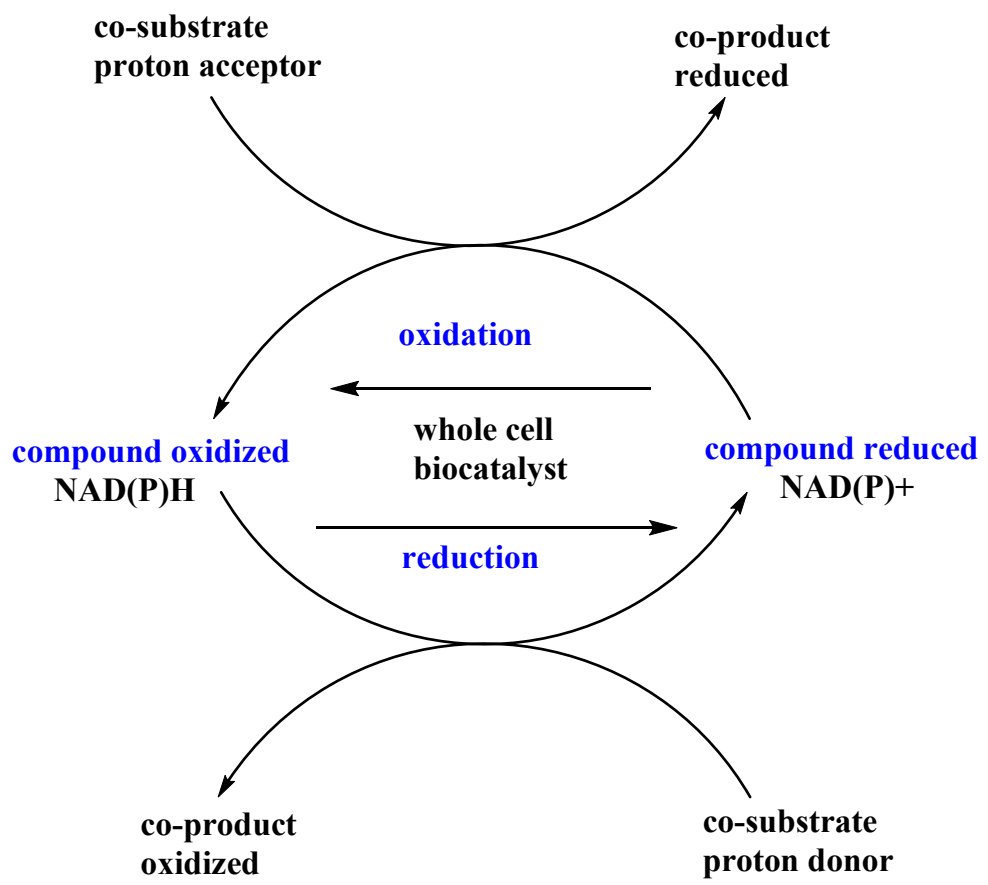

Figure 7. Co-substrates in oxidation and reduction reactions.

\subsection{Affecting the Coenzyme Regeneration System}

\subsubsection{Chemical Additives in Asymmetric Reductions}

Microbial asymmetric reduction of prochiral ketones is the most well-known methodology for the preparation of chiral secondary alcohols with a theoretical conversion rate of $100 \%$. Reductases and dehydrogenases mainly participate in reduction processes; therefore, the selection of an appropriate co-substrate and its amount are crucial for effective coenzyme regeneration. The co-substrates are usually oxidized (after serving as hydrogen donors) by the activity of dehydrogenases in the microbial cells and then participate in the regeneration of the reduced cofactors (Figure 7). Examples of the most popular chemicals used as co-substrates in bioreductions are, among others, ethanol, glucose, and isopropanol [91,92].

Glucose added to the biotransformation medium is used by microorganisms as a source of carbon and energy, ensuring the proper course and level of metabolic pathways. This sugar is sometimes also applied as a co-substrate, providing evidence for the ability of the selected microorganisms to use carbohydrates for regeneration of the coenzyme $(\mathrm{NAD}(\mathrm{P}) \mathrm{H})$ by respiratory metabolic pathways [9]. Cells' glucose dehydrogenase oxidizes glucose to gluconic acid with simultaneous reduction of $\mathrm{NAD}(\mathrm{P})^{+}$. This makes it possible to obtain a proper form of the coenzyme for the reduction of the substrate introduced to the system. An additional advantage of such an approach is the lack of competition between sugar and the bioreduction substrate for the active site of the enzyme directly involved in the desired biotransformation. 
The importance of glucose as a co-substrate in cofactor regeneration has been tested during the asymmetric reduction of 3,5-bis(trifluoromethyl)acetophenone yielding (S)-3,5bis(trifluoromethyl)phenylethanol. The reaction was catalyzed by Rhodotorula mucilaginosa NQ1 cells of proven carbonyl reductase activity. The addition of glucose (in sufficient quantity) to the reaction environment promoted the regeneration of NADPH and thus the process yield was increased up to $90 \%$ and the corresponding alcohol was obtained as a product with $96 \%$ enantiomeric excess, while the blank control (without glucose) led to a yield of $3 \%$ and less than $70 \%$ e.e. [93].

Additionally, for the asymmetric reduction of 4-hydroxy-2-butanone-the second step in the cascade reaction applied for deracemization of 1,3-butanediol to the corresponding (R)-1,3-butanediol-glucose has been used as a co-substrate to regenerate the NADPH coenzyme, and this made it possible to increase the reaction yield from less than $20 \%$ to $83.35 \%$. The process was catalyzed by Pichia kudriayzeyii QC-1 cells with $(R)$-specific carbonyl reductase activity and resulted in product formation with excellent enantiomeric excess (99.5\% e.e.) [94].

Other low molecular weight co-substrates often used to support reduction reactions based on the activity of reductases or dehydrogenases are 2-propanol, ethanol, and formic acid. Ethanol and 2-propanol are usually applied to regenerate oxidized coenzymes in reactions where one enzyme is both responsible for substrate transformation and is part of the reducing equivalents' regeneration system. Therefore, the amounts of these factors must be carefully selected to avoid competition between the substrate and co-substrate for the active side of the enzyme involved in the desired reaction. Additionally, in the discussed case, the toxic effects of ethanol and the products arising after 2-propanol conversion (acetone) on the biocatalyst should be taken into consideration and should influence the co-substrate concentration chosen.

As an example, we can cite the asymmetric bioreduction of two $\alpha$-nitro ketones catalyzed by cells of the bacterium Comamonas testosteroni DSM 1455 with the use of 2propanol as co-substrate for coenzyme regeneration. Isopropanol, as a hydrogen donor, was converted to acetone with simultaneous reduction of the coenzyme. The final products, corresponding to (S)- $\beta$-nitroalcohols, were obtained as an effect of alcohol dehydrogenase activity and the yield was about $47-75 \%$ and the enantiomeric excess was higher than $98 \%$ [95].

The previously mentioned acetophenone derivative bioreductions utilizing Empedobacter brevis ZJUY-1401 were effective for the selection of an appropriate and effective method of coenzyme regeneration, apart from the significance of the substituents. Among the tested additives (i.e., ethanol, 2-propanol, glucose, maltose, glycerol, methanol), ethanol at a concentration of $10 \%$ turned out to be the most effective and made it possible to obtain optically pure products conversion with conversion rates of 15-99\%. In one study, ethanol was used not only as a co-substrate for effective coenzyme regeneration, but also acted as a co-solvent, increasing the solubility of the substrates in the reaction medium [7].

\subsubsection{Chemical Additives in Asymmetric Oxidation}

Dehydrogenases also catalyze oxidation reactions, which can be applied in the resolution of racemic mixtures of chiral secondary alcohols. As a result, one of the enantiomers was obtained in a study that used this kind of reaction. Alcohol dehydrogenases catalyze the substrate oxidation, utilizing the oxidized nicotinamide cofactors $\left(\mathrm{NAD}(\mathrm{P})^{+}\right)$as proton and electron acceptors; therefore, an efficient system of coenzyme regeneration is also crucial to carry out this kind of process. Effective regeneration of the oxidized form of the coenzymes $\left(\mathrm{NAD}(\mathrm{P})^{+}\right)$requires co-substrates, which will be reduced as the reaction progresses (Figure 7). The most commonly used reducible additive is acetone, which gives 2-propanol as the side product.

An interesting solution in the synthesis of enantiomerically pure alcohols is the cascade oxidation-reduction system for $(R)$-1,3-butanediol production from its racemate. $(R)-1,3-$ butanediol is an important chiral alcohol used as an intermediate for the synthesis of 
high-value compounds [96] as well as critical pharmaceutical intermediates [97]. First, the oxidative step was catalyzed by Candida parapsilosis cells with the addition of acetone as a co-substrate for the coenzyme regeneration system. The use of acetone resulted in the synthesis of 4-hydroxy-2-butanone ( $45 \%$ yield, $97 \%$ e.e.) as an effect of the oxidative activity of dehydrogenase exhibiting an $S$-enantiopreference. For the $R$-enantiopreference of the reduction step, catalyzed by Pichia kudriavzevii QC-1R, glucose ( $24 \mathrm{~g} / \mathrm{L})$ was introduced into the medium. This allowed formation of a product with $83.35 \%$ yield and $99.5 \%$ e.e. [94].

\subsubsection{Oxidase-Based Resolution of Racemic Mixtures}

As mentioned earlier, the corresponding enantiomerically pure isomers of secondary alcohols or amine derivatives can be obtained by kinetic resolution of their racemic mixtures due to the activity of other enzymes, e.g., oxidases also present in microbial cells. As previously, in this case, the selection of appropriate reaction parameters, including the choice of co-substrate, is crucial to effectively obtain the desired product with high enantiomeric purity.

As an example of the oxidative kinetic resolution of the racemic mixture, we can cite the reaction catalyzed by the fungus Beauveria bassiana. This mold was capable of enantioselectively oxidizing the hydroxyl group of one of the enantiomers of diethyl 1-hydroxy-1-phenylmethanephosphonate (Figure 8), leaving the other one unreacted.<smiles>CCOC(O)c1ccccc1</smiles>

Figure 8. Racemic mixture of diethyl 1-hydroxy-1-phenylmethanephosphonate. Based on [98] with permission.

The tested biocatalyst exhibited different stereoselectivities of biooxidation depending on the preincubation conditions. The best method to control the enantioselectivity of the process was the use of cyclohexanone as a co-substrate. The application of this additive implied an absolute configuration in the enriching of the racemic mixture of the substrate in the enantiomer of $R$, while the experiment carried out without any co-substrate enabled a slight increase in the amount of the $S$ isomer after the bioconversion. In this last case, the e.e. values (about $20 \%$ ) were not satisfactory. However, this procedure is worth developing because of its simplicity and the possibility of obtaining both enantiomers of the substrate. Researchers have speculated that the different enantioselectivities of the oxidation are due to the fact that cyclohexanone and the substrate (hydroxyphosphonate) serve as parts of the cellular coenzyme regeneration system necessary for oxidase activity. A sufficient amount of cyclohexanone supports the production of oxidized forms of the coenzymes, which, in one study, were then used as proton acceptors for the main substrate oxidation [98].

All the factors that may influence the enantioselectivity of the biocatalyzed reactions described are presented below in Table 2. 
Table 2. Examples of processes influenced by different physicochemical factors.

\begin{tabular}{|c|c|c|c|c|}
\hline Type of Modification & Advantages of the Process & $\begin{array}{c}\text { Disadvantages of } \\
\text { the Process }\end{array}$ & Examples of Processes & Ref. \\
\hline \multirow{2}{*}{$\begin{array}{l}\text { Biocatalyst cultivation } \\
\text { under different } \\
\text { conditions }\end{array}$} & \multirow{2}{*}{$\begin{array}{l}\text { Possible activation of } \\
\text { different groups of enzymes } \\
\text { with the desired activity and } \\
\text { enantioselectivity. } \\
\text { Starvation conditions may } \\
\text { trigger alternative metabolic } \\
\text { paths and modes of transport } \\
\text { across the cell membrane }\end{array}$} & \multirow{2}{*}{$\begin{array}{l}\text { Improperly selected } \\
\text { conditions can lead to } \\
\text { reductions in selectivity } \\
\text { and even cell death }\end{array}$} & $\begin{array}{l}\text { Kinetic resolution of racemic } \\
\text { aminophosphonate based on } \\
\text { oxidase activity preceded by } \\
\text { a pre-incubation stage under } \\
\text { starvation conditions }\end{array}$ & [14-17] \\
\hline & & & $\begin{array}{l}\text { Kinetic resolution of racemic } \\
\text { aminophosphonate based on } \\
\text { oxidase activity preceded by } \\
\text { cultivation on different } \\
\text { media (YM or PDB) }\end{array}$ & [15] \\
\hline \multirow{3}{*}{ Immobilization } & \multirow{3}{*}{$\begin{array}{l}\text { Stabilization of biocatalyst } \\
\text { activity, resistance to the } \\
\text { toxicity of the reagents. } \\
\text { Possible switch of some } \\
\text { enzymes bounded with the } \\
\text { cell envelope }\end{array}$} & \multirow{3}{*}{$\begin{array}{l}\text { Possible decrease in } \\
\text { activity; difficulties in } \\
\text { mass transport }\end{array}$} & $\begin{array}{l}\text { Enantioselective conversion } \\
\text { of racemic substrates with } \\
\text { biocatalysts immobilized in } \\
\text { calcium alginate }\end{array}$ & [28-30] \\
\hline & & & $\begin{array}{c}\text { Enantioselective hydrolysis } \\
\text { of racemic mandelonitrile } \\
\text { with biocatalysts } \\
\text { immobilized in alginate } \\
\text { biocatalyst }\end{array}$ & {$[32]$} \\
\hline & & & $\begin{array}{l}\text { Enantioselective oxidative } \\
\text { deamination with } \\
\text { biocatalysts immobilized on } \\
\text { polyurethane foam or } \\
\text { entrapped in agar-agar }\end{array}$ & [33] \\
\hline \multirow{5}{*}{ Reaction parameters } & \multirow{5}{*}{$\begin{array}{l}\text { Properly selected, reaction } \\
\text { parameters ensure the } \\
\text { maximum level of activity of } \\
\text { a given group of enzymes. } \\
\text { By manipulating the pH or } \\
\text { temperature, it is possible to } \\
\text { deactivate isoenzymes with a } \\
\text { given stereoselectivity that } \\
\text { are more sensitive to external } \\
\text { factors or force the synthesis } \\
\text { of enzymes of a desired } \\
\text { activity after a longer } \\
\text { incubation time }\end{array}$} & \multirow{5}{*}{$\begin{array}{l}\text { Possible deactivation of } \\
\text { desired enzymes } \\
\text { caused by unsuitable } \\
\text { factors, such as } \\
\text { temperature, pH, and } \\
\text { mixing, etc., or the } \\
\text { viability of the cells }\end{array}$} & $\begin{array}{c}\text { Deracemization of aliphatic } \\
\beta \text {-ketoesters in } \\
\text { pH-optimized procedure }\end{array}$ & [37] \\
\hline & & & $\begin{array}{c}\text { Stereoinversion of } \\
\text { S-1-(1-naphtyl)ethanol in } \\
\text { optimal pH and temperature }\end{array}$ & [40] \\
\hline & & & $\begin{array}{c}\text { Enantioselective } \\
\text { bioreduction of cyclo- } \\
\text { hexyl(phenyl)methanone in } \\
\text { optimal pH and } \\
\text { agitation conditions }\end{array}$ & {$[41,42]$} \\
\hline & & & $\begin{array}{l}\text { Enantioselective hydrolysis } \\
\text { of racemic substrates with } \\
\text { optimal pH and temperature }\end{array}$ & [43] \\
\hline & & & $\begin{array}{l}\text { Asymmetric reduction of } \\
\text { acetophenone for the } \\
\text { optimal time }\end{array}$ & [46] \\
\hline
\end{tabular}

The location of the

Selectivity can be enhanced Substrate engineering by modifying the structure to ensure a perfect fit with the enzyme binding pocket substituent being in the wrong place may cause a decrease of activity or exclude the possibility of reaction through steric obstacles
Bioreduction of substituted acetophenones 
Table 2. Cont

\begin{tabular}{|c|c|c|c|c|}
\hline Type of Modification & Advantages of the Process & $\begin{array}{l}\text { Disadvantages of } \\
\text { the Process }\end{array}$ & Examples of Processes & Ref. \\
\hline \multirow{7}{*}{$\begin{array}{l}\text { Various solvents as } \\
\text { reaction media }\end{array}$} & \multirow{7}{*}{$\begin{array}{l}\text { Improving the solubility of } \\
\text { substrates and the } \\
\text { permeability of the cell } \\
\text { membrane }\end{array}$} & \multirow{7}{*}{$\begin{array}{l}\text { Toxic impact on the } \\
\text { viable cells; } \\
\text { destruction of cellular } \\
\text { envelope and lysis }\end{array}$} & $\begin{array}{c}\text { Kinetic resolution of racemic } \\
\text { epoxide in a mixture of solvents }\end{array}$ & [57] \\
\hline & & & $\begin{array}{l}\text { Selective biooxidation of racemic } \\
\text { diol in a biphasic system }\end{array}$ & [58] \\
\hline & & & $\begin{array}{l}\text { Enantioselective bioreductions } \\
\text { in ionic liquids }\end{array}$ & {$[65]$} \\
\hline & & & $\begin{array}{l}\text { Enantioselective bioreduction of } \\
\text { aryl ketones with addition of } \\
\text { hydrophilic ionic liquids }\end{array}$ & {$[9,66]$} \\
\hline & & & $\begin{array}{l}\text { Bioreduction of different ketones } \\
\text { in deep eutectic solvent with } \\
\text { water addition }\end{array}$ & [71-75] \\
\hline & & & $\begin{array}{l}\text { Asymmetric bioreduction in } \\
\text { natural deep eutectic solvents } \\
\text { mixed with water }\end{array}$ & {$[77]$} \\
\hline & & & $\begin{array}{l}\text { Bioreduction of aromatic ketones } \\
\text { in supercritical carbon dioxide }\end{array}$ & [87] \\
\hline \multirow{5}{*}{ Chemical additives } & \multirow{5}{*}{$\begin{array}{l}\text { Chemical additives affect } \\
\text { dehydrogenase activity via } \\
\text { the impact on the balance } \\
\text { between the oxidized and } \\
\text { reduced forms of coenzymes. } \\
\text { They can also act as proton } \\
\text { acceptors or donors, } \\
\text { interfering only with the } \\
\text { cellular cofactor regeneration } \\
\text { system, or they can affect the } \\
\text { redox paths as substrates or } \\
\text { intermediates }\end{array}$} & \multirow{5}{*}{$\begin{array}{l}\text { If the wrong amount } \\
\text { is used, the activity of } \\
\text { the biocatalyst can be } \\
\text { deactivated, mostly } \\
\text { as an effect of toxicity } \\
\text { or the disruption of } \\
\text { cell integrity }\end{array}$} & $\begin{array}{l}\text { Asymmetric bioreduction with } \\
\text { glucose as a co-substrate }\end{array}$ & {$[93,94]$} \\
\hline & & & $\begin{array}{l}\text { Asymmetric bioreduction with } \\
\text { ethanol as a co-substrate }\end{array}$ & [7] \\
\hline & & & $\begin{array}{l}\text { Asymmetric bioreduction with } \\
\text { 2-propanol as a co-substrate }\end{array}$ & [95] \\
\hline & & & $\begin{array}{l}\text { Selective cascade } \\
\text { oxidation-reduction system with } \\
\text { acetone and glucose as a } \\
\text { co-substrates }\end{array}$ & [94] \\
\hline & & & $\begin{array}{l}\text { Enantioselective oxidative } \\
\text { kinetic resolution of } \\
\text { hydroxyphosphonate with } \\
\text { cyclohexanone as a co-substrate }\end{array}$ & [98] \\
\hline
\end{tabular}

\section{Conclusions}

Whole-cell biocatalysts, due to the presence of enzymes of various activities and thanks to their incredible metabolic flexibility, may be an attractive alternative to isolated enzymes or genetically modified cells. Furthermore, there are known simple and effective physicochemical methods of manipulating the enantioselectivity of the biotransformation process. The selection of the optimal culture conditions or the composition of the reaction medium, including the use of various solvents and co-solvents, makes it not only possible to transform poorly water-soluble substrates, but also, through the use of media such as ionic liquids or eutectics, enables the enantioselectivity of the reaction to be changed, either by increasing the permeability of the cell membrane or by inactivating membrane proteins. Also, the use of various additives that serve as coenzyme regenerators makes it possible to increase the effectiveness of selected enzymes (e.g., oxidase dehydrogenase) of specific enantioselectivities. On the other hand, different immobilization protocols, which influence the transport across the membranes and exert an influence through interactions with integral proteins of enzymatic activity, e.g., dehydrogenase, can result in two different enantiomers of a product, even with the use of one biocatalyst. 
Author Contributions: Conceptualization, M.B.-R. and A.R.; writing-original draft preparation, A.R., J.J. and M.B.-R.; writing-review and editing, A.R. and M.B.-R. All authors have read and agreed to the published version of the manuscript.

Funding: The work was supported by a subsidy from the Polish Ministry of Science and Higher Education for the Faculty of Chemistry of Wroclaw University of Science and Technology. This research work was financially supported by the National Science Centre, Poland, grant no. 2016/23/B/NZ9/02721.

Conflicts of Interest: The authors declare no conflict of interest.

\section{References}

1. Lin, B.; Tao, Y. Whole-cell biocatalysts by design. Microb. Cell Factories 2017, 16, 106. [CrossRef]

2. Sheldon, R.A.; Woodley, J. Role of Biocatalysis in Sustainable Chemistry. Chem. Rev. 2018, 118, 801-838. [CrossRef] [PubMed]

3. Wu, S.; Snajdrova, R.; Moore, J.C.; Baldenius, K.; Bornscheuer, U.T. Biocatalysis: Enzymatic Synthesis for Industrial Applications. Angew. Chem. Int. Ed. 2021, 60, 88-119. [CrossRef] [PubMed]

4. Sheldon, R.A.; Brady, D. The limits to biocatalysis: Pushing the envelope. Chem. Commun. 2018, 54, 6088-6104. [CrossRef]

5. D'Amato, R.J.; Loughnan, M.S.; Flynn, E.; Folkman, J. Thalidomide is an inhibitor of angiogenesis. Proc. Natl. Acad. Sci. USA 1994, 91, 4082-4085. [CrossRef]

6. Du, P.-X.; Wei, P.; Lou, W.-Y.; Zong, M.-H. Biocatalytic anti-Prelog reduction of prochiral ketones with whole cells of Acetobacter pasteurianus GIM1.158. Microb. Cell Factories 2014, 13, 84. [CrossRef]

7. Li, A.; Ye, L.; Guo, F.; Yang, X.; Yu, H. Biocatalytic anti-Prelog reduction of prochiral ketones with whole cells of a newly isolated strain Empedobacter brevis ZJUY-1401. J. Mol. Catal. B Enzym. 2015, 117, 31-37. [CrossRef]

8. Prelog, V. Specification of the stereospecificity of some oxido-reductases by diamond lattice sections. Pure Appl. Chem. 1964, 9, 119-130. [CrossRef]

9. Garzón-Posse, F.; Becerra-Figueroa, L.; Hernández-Arias, J.; Gamba-Sánchez, D. Whole Cells as Biocatalysts in Organic Transformations. Molecules 2018, 23, 1265. [CrossRef]

10. Kazlauskas, R.; Weissfloch, A.N.E.; Rappaport, A.T.; Cuccia, L.A. A rule to predict which enantiomer of a secondary alcohol reacts faster in reactions catalyzed by cholesterol esterase, lipase from Pseudomonas cepacia, and lipase from Candida rugosa. J. Org. Chem. 1991, 56, 2656-2665. [CrossRef]

11. Melais, N.; Aribi-Zouioueche, L.; Riant, O. The effect of the migrating group structure on enantioselectivity in lipase-catalyzed kinetic resolution of 1-phenylethanol. Comptes Rendus Chim. 2016, 19, 971-977. [CrossRef]

12. Gandomkar, S.; Jost, E.; Loidolt, D.; Swoboda, A.; Pickl, M.; Elaily, W.; Daniel, B.; Fraaije, M.W.; Macheroux, P.; Kroutil, W. Biocatalytic Enantioselective Oxidation of Sec -Allylic Alcohols with Flavin-Dependent Oxidases. Adv. Synth. Catal. 2019, 361, 5264-5271. [CrossRef]

13. Górak, M.; Żymańczyk-Duda, E. Application of cyanobacteria for chiral phosphonate synthesis. Green Chem. 2015, 17, 4570-4578. [CrossRef]

14. Serafin-Lewańczuk, M.; Klimek-Ochab, M.; Brzezińska-Rodak, M.; Żymańczyk-Duda, E. Fungal synthesis of chiral phos-phonic synthetic platform-Scope and limitations of the method. Bioorg. Chem. 2018, 77, 402-410. [CrossRef] [PubMed]

15. Serafin-Lewańczuk, M.; Brzezińska-Rodak, M.; Lubiak-Kozłowska, K.; Majewska, P.; Klimek-Ochab, M.; Olszewski, T.K.; Żymańczyk-Duda, E. Phosphonates enantiomers receiving with fungal enzymatic systems. Microb. Cell Factories 2021, $20,1-14$. [CrossRef] [PubMed]

16. Kozyra, K.; Brzezińska-Rodak, M.; Klimek-Ochab, M.; Żymańczyk-Duda, E. Biocatalyzed kinetic resolution of racemic mixtures of chiral $\alpha$-aminophosphonic acids. J. Mol. Catal. B Enzym. 2013, 91, 32-36. [CrossRef]

17. Lubiak-Kozłowska, K.; Brzezińska-Rodak, M.; Klimek-Ochab, M.; Olszewski, T.K.; Serafin-Lewańczuk, M.; Żymańczyk-Duda, E. (S)-Thienyl and (R)-Pirydyl phosphonate Derivatives Synthesized by Stereoselective Resolution of Their Racemic Mixtures With Rhodotorula mucilaginosa (DSM 70403)—Scaling Approaches. Front. Chem. 2020, 8, 589720. [CrossRef] [PubMed]

18. Klibanov, A.M. Immobilized Enzymes and Cells as Practical Catalysts. Science 1983, 219, 722-727. [CrossRef]

19. Bilal, M.; Zhao, Y.; Noreen, S.; Shah, S.Z.H.; Bharagava, R.N.; Iqbal, H.M.N. Modifying bio-catalytic properties of enzymes for efficient biocatalysis: A review from immobilization strategies viewpoint. Biocatal. Biotransform. 2019, 37, 159-182. [CrossRef]

20. Sheldon, R.A.; Van Pelt, S. Enzyme immobilisation in biocatalysis: Why, what and how. Chem. Soc. Rev. 2013, 42, 6223-6235. [CrossRef] [PubMed]

21. Jesionowski, T.; Zdarta, J.; Krajewska, B. Enzyme immobilization by adsorption: A review. Adsorption 2014, 20, 801-821. [CrossRef]

22. Qiu, S.; Wang, Y.-J.; Yu, H.; Cheng, F.; Zheng, Y.-G. t-Butyl 6-cyano-(3R,5R)-dihydroxyhexanoate synthesis via asymmetric reduction by immobilized cells of carbonyl reductase and glucose dehydrogenase co-expression E. coli. Process. Biochem. 2019, 80, 43-51. [CrossRef]

23. Kisukuri, C.M.; Andrade, L.H. Production of chiral compounds using immobilized cells as a source of biocatalysts. Org. Biomol. Chem. 2015, 13, 10086-10107. [CrossRef] [PubMed]

24. Nguyen, H.H.; Kim, A.M. An Overview of Techniques in Enzyme Immobilization. Appl. Sci. Converg. Technol. 2017, 26, 157-163. [CrossRef] 
25. Nagaoka, T.; Shiigi, H.; Tokonami, S.; Saimatsu, K. Entrapment of Whole Cell Bacteria into Conducting Polymers. J. Flow Inject. Anal. 2012, 29, 7-10. Available online: https://www.jstage.jst.go.jp/article/jfia/29/1/29_7/pdf/-char/en (accessed on 23 June 2021).

26. Kermasha, S.; Gibbs, B.F. Encapsulation in the food industry: A review. Int. J. Food Sci. Nutr. 1999, 50, 213-224. [CrossRef]

27. Rathore, S.; Desai, P.M.; Liew, C.V.; Chan, L.W.; Heng, P.W.S. Microencapsulation of microbial cells. J. Food Eng. 2013, $116,369-381$. [CrossRef]

28. Swetha, E.; Vijitha, C.; Veeresham, C. Enantioselective Conversion of Racemic Sotalol to R(-)-Sotalol by Lipase AP6. Indian J. Pharm. Sci. 2018, 80, 676-685. [CrossRef]

29. Vijitha, C.; Swetha, E.; Veeresham, C. Enantioselective Conversion of Racemic Felodipine to S(-)-Felodipine by Aspergillus niger and Lipase AP6 Enzyme. Adv. Microbiol. 2016, 6, 1062-1074. [CrossRef]

30. Ettireddy, S.; Chandupatla, V.; Veeresham, C. Enantioselective Resolution of (R,S)-Carvedilol to (S)-(-)-Carvedilol by Biocatalysts. Nat. Prod. Bioprospect. 2017, 7, 171-179. [CrossRef] [PubMed]

31. Xue, Y.-P.; Xu, S.-Z.; Liu, Z.-Q.; Zheng, Y.-G.; Shen, Y.-C. Enantioselective biocatalytic hydrolysis of (R,S)-mandelonitrile for production of (R)-(-)-mandelic acid by a newly isolated mutant strain. J. Ind. Microbiol. Biotechnol. 2011, 38, 337-345. [CrossRef]

32. Xue, Y.-P.; Xu, M.; Chen, H.-S.; Liu, Z.-Q.; Wang, Y.-J.; Zheng, Y.-G. A Novel Integrated Bioprocess for Efficient Production of (R)-(-)-Mandelic Acid with ImmobilizedAlcaligenes faecalisZJUTB10. Org. Process. Res. Dev. 2013, 17, 213-220. [CrossRef]

33. Żymańczyk-Duda, E.; Dunal, N.; Brzezińska-Rodak, M.; Osiewała, A.; Olszewski, T.; Klimek-Ochab, M.; Serafin-Lewańczuk, M. First biological conversion of chiral heterophosphonate derivative-Scaling and paths of conversion discussion. Bioorg. Chem. 2019, 93, 102751. [CrossRef]

34. Ghaffari-Moghaddam, M.; Eslahi, H.; Aydin, Y.A.; Saloglu, D. Enzymatic processes in alternative reaction media: A mini review. J. Biol. Methods 2015, 2, e25. [CrossRef]

35. Cuesta, S.M.; Rahman, S.A.; Furnham, N.; Thornton, J.M. The Classification and Evolution of Enzyme Function. Biophys. J. 2015, 109, 1082-1086. [CrossRef]

36. Lau, P.C.; Grosse, S. The fundamentals and fun of biocatalysis. In Marine Enzymes for Biocatalysis: Sources, Biocatalytic Characteristics and Bioprocesses of Marine Enzymes; Woodhead Publishing Limited: Sawston, UK, 2013. [CrossRef]

37. Venkataraman, S.; Chadha, A. Biocatalytic deracemisation of aliphatic $\beta$-hydroxy esters: Improving the enantioselectivity by optimisation of reaction parameters. J. Ind. Microbiol. Biotechnol. 2015, 42, 173-180. [CrossRef]

38. Hasegawa, J.; Ogura, M.; Tsuda, S.; Maemoto, S.-I.; Kutsuki, H.; Ohashi, T. High-yield Production of Optically Active 1,2-Diols from the Corresponding Racemates by Microbial Stereoinversion. Agric. Biol. Chem. 1990, 54, 1819-1827. [CrossRef]

39. Kaliaperumal, T.; Gummadi, S.N.; Chadha, A. Candida parapsilosisATCC 7330 can also deracemise 1-arylethanols. Biocatal. Biotransform. 2011, 29, 262-270. [CrossRef]

40. Amrutkar, S.M.; Banoth, L.; Banerjee, U.C. One-pot synthesis of (R)-1-(1-naphthyl)ethanol by stereoinversion using Candida parapsilosis. Tetrahedron Lett. 2013, 54, 3274-3277. [CrossRef]

41. Şahin, E.; Serencam, H.; Dertli, E. Whole cell application of Lactobacillus paracasei BD101 to produce enantiomerically pure (S)-cyclohexyl(phenyl)methanol. Chirality 2019, 31, 211-218. [CrossRef] [PubMed]

42. Şahin, E. Production of (R )-1-(1,3-benzodioxol-5-yl)ethanol in high enantiomeric purity by Lactobacillus paracasei BD101. Chirality 2018, 30, 189-194. [CrossRef]

43. Chen, Y.; Zhang, X.; Zheng, G.; Gao, S. Preparation of the enantiomerically enriched precursor of lamivudine (3TC $\left.{ }^{\mathrm{TM}}\right)$ via asymmetric catalysis mediated by Klebsiella oxytoca. Process. Biochem. 2019, 81, 77-84. [CrossRef]

44. Ramos-Martín, J.; Khiari, O.; Alcántara, A.; Sánchez-Montero, J. Biocatalysis at Extreme Temperatures: Enantioselective Synthesis of both Enantiomers of Mandelic Acid by Transesterification Catalyzed by a Thermophilic Lipase in Ionic Liquids at $120{ }^{\circ} \mathrm{C}$. Catalysts 2020, 10, 1055. [CrossRef]

45. Sun, J.; Huang, J.; Ding, X.; Wang, P. Efficient Enantioselective Biocatalytic Production of a Chiral Intermediate of Sitagliptin by a Newly Filamentous Fungus Isolate. Appl. Biochem. Biotechnol. 2016, 180, 695-706. [CrossRef] [PubMed]

46. Şahin, E.; Dertli, E. Highly Enantioselective Production of Chiral Secondary Alcohols with Candida zeylanoides as a New Whole Cell Biocatalyst. Chem. Biodivers. 2017, 14, e1700121. [CrossRef] [PubMed]

47. Pölloth, B.; Sibi, M.P.; Zipse, H. The Size-Accelerated Kinetic Resolution of Secondary Alcohols. Angew. Chem. Int. Ed. 2021, 60, 774-778. [CrossRef]

48. Chen, C.-A.; Sih, C.J. Chemoenzymatic Synthesis of Conjugated Linoleic Acid. J. Org. Chem. 1998, 63, 9620-9621. [CrossRef]

49. Adamczyk, M.; Chen, Y.-Y.; Fishpaugh, J.R.; Gebler, J.C. Lipase mediated diastereoselective hydrolysis of steroidal 3-(Ocarboxymethyl) oxime methyl esters. Tetrahedron Asymmetry 1993, 4, 1467-1468. [CrossRef]

50. Lopes, R.D.O.; Ribeiro, J.B.; Ramos, A.D.S.; Miranda, L.S.; Leal, I.C.R.; Leite, S.G.F.; De Souza, R.O.M.A. Highly enantioselective bioreduction of 4-bromoacetophenone. Tetrahedron Asymmetry 2011, 22, 1763-1766. [CrossRef]

51. Cao, C.; Matsuda, T. Biocatalysis in Organic Solvents, Supercritical Fluids and Ionic Liquids. In Organic Synthesis Using Biocatalysis; Elsevier: Amsterdam, The Netherlands, 2016; pp. 67-97.

52. Yang, Z.; Pan, W. Ionic liquids: Green solvents for nonaqueous biocatalysis. Enzym. Microb. Technol. 2005, 37, 19-28. [CrossRef]

53. Pätzold, M.; Siebenhaller, S.; Kara, S.; Liese, A.; Syldatk, C.; Holtmann, D. Deep Eutectic Solvents as Efficient Solvents in Biocatalysis. Trends Biotechnol. 2019, 37, 943-959. [CrossRef]

54. Klibanov, A.M. Improving enzymes by using them in organic solvents. Nat. Cell Biol. 2001, 409, 241-246. [CrossRef] [PubMed] 
55. Laane, C.; Boeren, S.; Vos, K.; Veeger, C. Rules for optimization of biocatalysis in organic solvents. Biotechnol. Bioeng. 1987, 30, 81-87. [CrossRef]

56. Belafriekh, A.; Secundo, F.; Serra, S.; Djeghaba, Z. Enantioselective enzymatic resolution of racemic alcohols by lipases in green organic solvents. Tetrahedron Asymmetry 2017, 28, 473-478. [CrossRef]

57. Matsumoto, M.; Sugimoto, T.; Ishiguro, Y.; Yamaguchi, H.; Kondo, K. Effect of organic solvents and ionic liquids on resolution of 2-epoxyhexane by whole cells of Rhodotorula glutinis in a two-liquid phase system. J. Chem. Technol. Biotechnol. 2013, 89, 522-527. [CrossRef]

58. Peng, F.; Zhao, Y.; Li, F.-Z.; Ou, X.-Y.; Zeng, Y.-J.; Zong, M.-H.; Lou, W.-Y. Highly enantioselective resolution of racemic 1-phenyl1,2-ethanediol to (S)-1-phenyl-1,2-ethanediol by Kurthia gibsonii SC0312 in a biphasic system. J. Biotechnol. 2020, 308, 21-26. [CrossRef] [PubMed]

59. Welton, T. Ionic liquids: A brief history. Biophys. Rev. 2018, 10, 691-706. [CrossRef]

60. Vanda, H.; Dai, Y.; Wilson, E.G.; Verpoorte, R.; Choi, Y.H. Green solvents from ionic liquids and deep eutectic solvents to natural deep eutectic solvents. Comptes Rendus Chim. 2018, 21, 628-638. [CrossRef]

61. Moniruzzaman, M.; Nakashima, K.; Kamiya, N.; Goto, M. Recent advances of enzymatic reactions in ionic liquids. Biochem. Eng. J. 2010, 48, 295-314. [CrossRef]

62. Uddin, M.N.; Basak, D.; Hopefl, R.; Minofar, B. Potential Application of Ionic Liquids in Pharmaceutical Dosage Forms for Small Molecule Drug and Vaccine Delivery System. J. Pharm. Pharm. Sci. 2020, 23, 158-176. [CrossRef]

63. Egorova, K.S.; Gordeev, E.G.; Ananikov, V.P. Biological Activity of Ionic Liquids and Their Application in Pharmaceutics and Medicine. Chem. Rev. 2017, 117, 7132-7189. [CrossRef] [PubMed]

64. Greer, A.J.; Jacquemin, J.; Hardacre, C. Industrial Applications of Ionic Liquids. Molecules 2020, 25, 5207. [CrossRef] [PubMed]

65. Xu, J.; Zhou, S.; Zhao, Y.; Xia, J.; Liu, X.; Xu, J.; He, B.; Wu, B.; Zhang, J. Asymmetric whole-cell bioreduction of sterically bulky 2-benzoylpyridine derivatives in aqueous hydrophilic ionic liquid media. Chem. Eng. J. 2017, 316, 919-927. [CrossRef]

66. Xiao, Z.-J.; Du, P.-X.; Lou, W.-Y.; Wu, H.; Zong, M.-H. Using water-miscible ionic liquids to improve the biocatalytic anti-Prelog asymmetric reduction of prochiral ketones with whole cells of Acetobacter sp. CCTCC M209061. Chem. Eng. Sci. 2012, 84, 695-705. [CrossRef]

67. Choi, H.J.; Uhm, K.-N.; Kim, H.-K. Production of chiral compound using recombinant Escherichia coli cells co-expressing reductase and glucose dehydrogenase in an ionic liquid/water two phase system. J. Mol. Catal. B Enzym. 2011, 70, 114-118. [CrossRef]

68. Castiglione, K.; Fu, Y.; Polte, I.; Leupold, S.; Meo, A.; Weuster-Botz, D. Asymmetric whole-cell bioreduction of (R)-carvone by recombinant Escherichia coli with in situ substrate supply and product removal. Biochem. Eng. J. 2017, 117, 102-111. [CrossRef]

69. Peng, Q.; Wang, X.; Shang, M.; Huang, J.; Guan, G.; Li, Y.; Shi, B. Isolation of a novel alkaline-stable lipase from a metagenomic library and its specific application for milkfat flavor production. Microb. Cell Factories 2014, 13, 1. [CrossRef]

70. Zhang, Q.; Vigier, K.D.O.; Royer, S.; Jerome, F. Deep eutectic solvents: Syntheses, properties and applications. Chem. Soc. Rev. 2012, 41, 7108-7146. [CrossRef]

71. Bubalo, M.C.; Mazur, M.; Radošević, K.; Redovniković, I.R. Baker's yeast-mediated asymmetric reduction of ethyl 3-oxobutanoate in deep eutectic solvents. Process. Biochem. 2015, 50, 1788-1792. [CrossRef]

72. Maugeri, Z.; De María, P.D. Whole-Cell Biocatalysis in Deep-Eutectic-Solvents/Aqueous Mixtures. ChemCatChem 2014, 6, 1535-1537. [CrossRef]

73. Vitale, P.; Abbinante, V.M.; Perna, F.M.; Salomone, A.; Cardellicchio, C.; Capriati, V. Unveiling the Hidden Performance of Whole Cells in the Asymmetric Bioreduction of Aryl-containing Ketones in Aqueous Deep Eutectic Solvents. Adv. Synth. Catal. 2016, 359, 1049-1057. [CrossRef]

74. Xu, P.; Xu, Y.; Li, X.-F.; Zhao, B.-Y.; Zong, M.-H.; Lou, W.-Y. Enhancing Asymmetric Reduction of 3-Chloropropiophenone with Immobilized Acetobacter sp. CCTCC M209061 Cells by Using Deep Eutectic Solvents as Cosolvents. ACS Sustain. Chem. Eng. 2015, 3, 718-724. [CrossRef]

75. Chen, H.; Qian, F.; Lin, H.; Wang, P.; Chen, H.; Chen, W. Using Choline Chloride-Based DESs as Co-Solvent for 3,5Bis(trifluoromethyl) Acetophenone Bioreduction with Rhodococcus erythropolis XS1012. Catalysts 2019, 10, 30. [CrossRef]

76. Paiva, A.; Craveiro, R.; Aroso, I.; Martins, M.; Reis, R.L.; Duarte, A.R.C. Natural Deep Eutectic Solvents-Solvents for the 21st Century. ACS Sustain. Chem. Eng. 2014, 2, 1063-1071. [CrossRef]

77. Panić, M.; Elenkov, M.M.; Roje, M.; Bubalo, M.C.; Redovniković, I.R. Plant-mediated stereoselective biotransformations in natural deep eutectic solvents. Process. Biochem. 2018, 66, 133-139. [CrossRef]

78. Matsuda, T.; Marukado, R.; Mukouyama, M.; Harada, T.; Nakamura, K. Asymmetric reduction of ketones by Geotrichum candidum: Immobilization and application to reactions using supercritical carbon dioxide. Tetrahedron Asymmetry 2008, 19, $2272-2275$. [CrossRef]

79. Brandenbusch, C.; Bühler, B.; Hoffmann, P.; Sadowski, G.; Schmid, A. Efficient phase separation and product recovery in organic-aqueous bioprocessing using supercritical carbon dioxide. Biotechnol. Bioeng. 2010, 107, 642-651. [CrossRef]

80. Ütkür, F.Ö.; Tran, T.T.; Collins, J.; Brandenbusch, C.; Sadowski, G.; Schmid, A.; Bühler, B. Integrated organic-aqueous biocatalysis and product recovery for quinaldine hydroxylation catalyzed by living recombinant Pseudomonas putida. J. Ind. Microbiol. Biotechnol. 2012, 39, 1049-1059. [CrossRef] 
81. Brandenbusch, C.; Glonke, S.; Collins, J.; Hoffrogge, R.; Grunwald, K.; Bühler, B.; Schmid, A.; Sadowski, G. Process boundaries of irreversible scCO2-assisted phase separation in biphasic whole-cell biocatalysis. Biotechnol. Bioeng. 2015, 112, $2316-2323$. [CrossRef]

82. Liu, Y.; Chen, D.; Yan, Y. Effect of ionic liquids, organic solvents and supercritical CO2 pretreatment on the conformation and catalytic properties of Candida rugosa lipase. J. Mol. Catal. B Enzym. 2013, 90, 123-127. [CrossRef]

83. Lozano, P.; Bernal, J.M.; Vaultier, M. Towards continuous sustainable processes for enzymatic synthesis of biodiesel in hydrophobic ionic liquids/supercritical carbon dioxide biphasic systems. Fuel 2011, 90, 3461-3467. [CrossRef]

84. Badgujar, K.; Bhanage, B. Immobilization of lipase on biocompatible co-polymer of polyvinyl alcohol and chitosan for synthesis of laurate compounds in supercritical carbon dioxide using response surface methodology. Process. Biochem. 2015, 50, 1224-1236. [CrossRef]

85. Badgujar, V.C.; Badgujar, K.C.; Yeole, P.M.; Bhanage, B.M. Enhanced biocatalytic activity of immobilized steapsin lipase in supercritical carbon dioxide for production of biodiesel using waste cooking oil. Bioprocess Biosyst. Eng. 2018, $42,47-61$. [CrossRef] [PubMed]

86. Gremos, S.; Kekos, D.; Kolisis, F. Supercritical carbon dioxide biocatalysis as a novel and green methodology for the enzymatic acylation of fibrous cellulose in one step. Bioresour. Technol. 2012, 115, 96-101. [CrossRef] [PubMed]

87. Matsuda, T. Recent progress in biocatalysis using supercritical carbon dioxide. J. Biosci. Bioeng. 2013, 115, 233-241. [CrossRef]

88. Dos Santos, V.H.P.; Neto, D.M.C.; Júnior, V.L.; Borges, W.D.S.; Silva, E.D.O. Fungal Biotransformation: An Efficient Approach for Stereoselective Chemical Reactions. Curr. Org. Chem. 2020, 24, 2902-2953. [CrossRef]

89. Tassano, E.; Hall, M. Enzymatic self-sufficient hydride transfer processes. Chem. Soc. Rev. 2019, 48, 5596-5615. [CrossRef]

90. Puetz, H.; Puchl'ová, E.; Vranková, K.; Hollmann, F. Biocatalytic Oxidation of Alcohols. Catalysts 2020, 10, 952. [CrossRef]

91. Hoyos, P.; Sinisterra, J.-V.; Molinari, F.; Alcántara, A.R.; de María, P.D. Biocatalytic Strategies for the Asymmetric Synthesis of $\alpha$-Hydroxy Ketones. Acc. Chem. Res. 2010, 43, 288-299. [CrossRef]

92. Torres, E.; Ayala, M. Biocatalysis by Metalloenzymes. In Comprehensive Inorganic Chemistry II Vol. 6 Homogeneous Catalytic Applications, 2nd ed.; Kenneth, P., Ed.; Elsevier: Amsterdam, The Netherlands, 2013; Chapter 6.24; pp. 685-735. [CrossRef]

93. Wang, N.; Xu, Y.; Peng, C.; Wang, X.; Wei, Y.; Li, K.; Wang, S.; Xu, A.; Gao, J. Identification of a newly isolated Rhodotorula mucilaginosa NQ1 and its development for the synthesis of bulky carbonyl compounds by whole-cell bioreduction. Lett. Appl. Microbiol. 2021, 72, 399-407. [CrossRef]

94. Zu, H.; Gu, J.; Zhang, H.; Fan, A.; Nie, Y.; Xu, Y. Highly enantioselective synthesis of (R)-1,3-butanediol via deracemization of the corresponding racemate by a whole-cell stereoinverting cascade system. Microb. Cell Factories 2020, 19, 1-11. [CrossRef]

95. Rao, D.H.S.; Chatterjee, A.; Padhi, S.K. Biocatalytic approaches for enantio and diastereoselective synthesis of chiral $\beta$ nitroalcohols. Org. Biomol. Chem. 2021, 19, 322-337. [CrossRef] [PubMed]

96. Matsuda, T.; Yamanaka, R.; Nakamura, K. Recent progress in biocatalysis for asymmetric oxidation and reduction. Tetrahedron Asymmetry 2009, 20, 513-557. [CrossRef]

97. Iwata, H.; Tanaka, R.; Ishiguro, M. Structures of the alkaline hydrolysis products of penem antibiotic, SUN5555. J. Antibiot. 1990, 43, 901-903. [CrossRef] [PubMed]

98. Żymańczyk-Duda, E.; Brzezińska-Rodak, M.; Klimek-Ochab, M.; Lejczak, B. Application of the Beauveria bassiana Strain for the Enantioselective Oxidation of the Diethyl 1-Hydroxy-1-Phenylmethanephosphonate. Curr. Microbiol. 2011, 62, 1168-1172. [CrossRef] 